Article

\title{
Impact Injury at Harvest Promotes Body Rots in 'Hass' Avocado Fruit upon Ripening
}

\author{
Melinda L. Perkins ${ }^{1}{ }^{\circledR}$, Diane Usanase ${ }^{1}$, Bo Zhang ${ }^{1}$, Daryl C. Joyce ${ }^{1,2, *}$ and Lindy M. Coates ${ }^{2}$ \\ 1 School of Agriculture and Food Sciences, The University of Queensland, Gatton, QLD 4343, Australia; \\ m.perkins@uq.edu.au (M.L.P.); diane.usanase@uqconnect.edu.au (D.U.); bonbon3169@gmail.com (B.Z.) \\ 2 Department of Agriculture and Fisheries, Ecosciences Precinct, PO Box 267, Brisbane, QLD 4001, Australia; \\ Lindy.Coates@daf.qld.gov.au \\ * Correspondence: d.joyce@uq.edu.au
}

Received: 13 December 2019; Accepted: 6 January 2020; Published: 5 February 2020

\begin{abstract}
Global demand for avocados has risen rapidly in recent years, yet supplying fruit that consistently meets consumer expectations for quality remains a challenge in the industry. Body rots in avocado fruit are a leading cause of consumer dissatisfaction. Anecdotal evidence suggests that body rot development may be promoted by mechanical injury at harvest and packing, despite the fruit being hard, green and mature (i.e., unripe) at these stages. Here, 'Hass' avocado fruit, harvested across multiple fruiting seasons from commercial orchards, were subjected to controlled impact from drop heights of $15-60 \mathrm{~cm}$ at the time of harvest or packing. With increasing drop height, body rot development at eating ripe stage generally occurred more frequently and produced larger lesions at the impact site and, in some experiments, elsewhere on the fruit. These findings refute a general belief that green mature avocado fruit can tolerate a degree of rough physical handling without ripe fruit quality being compromised. Ideally, best avocado harvesting and packing practice should recognize that unripe fruit must not experience drop heights of $30 \mathrm{~cm}$ or higher.
\end{abstract}

Keywords: anthracnose; Colletotrichum; fruit quality; mechanical damage; Persea americana; postharvest disease

\section{Introduction}

Avocado has become an increasingly popular fruit in recent years, with global consumption experiencing annual growth rates of $\sim 4.6 \%$ [1]. Per capita consumption in Australia, for example, increased by $50 \%$ in the past five years from 2.5 to $3.8 \mathrm{~kg}$ [2]. Nonetheless, providing fruit that consistently meet consumers' quality expectations remains a challenge in the industry. Inconsistent quality was recently identified by more than half of avocado consumers as a barrier to purchase [3]. In another study, $45 \%$ of avocado shoppers felt dissatisfied with quality at least some of the time upon cutting the fruit at home [4]. Furthermore, around one in five 'Hass' avocado fruit sampled from Australian retail stores had internal defects affecting $>10 \%$ of the flesh [5]. This level of damage is known to result in consumer dissatisfaction [6].

Body rots are a leading internal defect of ripening avocado fruit. At the retail stage, they are second only to flesh bruising [5]. Body rots are principally anthracnose. This disease manifests when quiescent Colletotrichum infections, established in the orchard during fruit development, are released from latency in concert with postharvest ripening-related changes in the fruit. These changes include the degradation of antifungal compounds and increased tissue $\mathrm{pH}$ [7]. Body rot expression may, however, be exacerbated by the injury of mature green avocado fruit during harvesting and packing. In a recent study on flesh bruising in avocado, a proportion of the green mature fruit dropped from 50 
or $100 \mathrm{~cm}$ developed body rots at the impact site upon ripening. In contrast, non-impacted fruit had no rot development [8].

To date, research on impact injury in avocado fruit has focused mostly on flesh bruising. Mature green unripe fruit are hard and tend not to bruise upon impact $[8,9]$. This characteristic has led to a general assumption that gentle handling is not important at harvest and packing. Here, we hypothesised that impact injury during early stages in the supply chain may promote body rot development in the subsequently ripe fruit. Eight experiments were conducted across three seasons, with 'Hass' fruit sourced from two commercial orchards in south-east Queensland, Australia. Body rot development in fully ripe fruit in response to impact from drop heights of $0,15,30$ and $60 \mathrm{~cm}$ at harvest or packing was recorded separately for the impact site and elsewhere on the fruit. The influence of postharvest temperature and fungicide treatment on body rot development in impacted and non-impacted fruit were also investigated.

\section{Materials and Methods}

\subsection{Fruit Sampling and Maturity Determination}

Eight experiments using 'Hass' avocado fruit were conducted over three consecutive fruiting seasons. In the first year (2016), three experiments were conducted using fruit harvested from a commercial orchard in Spring Creek, Queensland, Australia $\left(27^{\circ} 26^{\prime} 10^{\prime \prime} \mathrm{S}, 152^{\circ} 20^{\prime} 2^{\prime \prime} \mathrm{E}\right)$. In the second and third years, two experiments were conducted in 2017 and three in 2018, using fruit harvested from a commercial orchard in Adare, Queensland, Australia $\left(27^{\circ} 31^{\prime} 36^{\prime \prime} \mathrm{S}, 152^{\circ} 18^{\prime} 12^{\prime \prime} \mathrm{E}\right)$. Unblemished fruit of consistent size and visual quality were harvested directly into fibreboard fruit trays with moulded plastic tray liners to prevent inadvertent mechanical injury. They were transported to the laboratory in an air-conditioned vehicle within $4 \mathrm{~h}$ of harvest and subjected to impact treatments either immediately (Experiments 1 to 6 ) or 1-4 d after harvest (Experiments 7 and 8). Impact treatments varied between experiments, and additional factors including ripeness stage at assessment, postharvest temperature regime and postharvest fungicide application were investigated in some experiments (Table 1).

Table 1. Summary of experiment time, fruit dry matter (DM) at harvest, treatment sample size $(n)$ and treatment details for each of the eight experiments.

\begin{tabular}{|c|c|c|c|c|c|c|c|}
\hline Experiment & Harvest Date & DM (\%) & $n$ & \multicolumn{4}{|c|}{ Treatment Factor } \\
\hline 1 & 13 June 2016 & 31 & 10 & $0,15,30,60$ & 20 & na & $S$ \\
\hline 4 & 10 July 2017 & 28 & 50 & $0,15,30,60$ & 20 & na & S \\
\hline 5 & 15 August 2017 & 32 & 50 & $0,15,30,60$ & 20 & na & $S$ \\
\hline 6 & 3 July 2018 & 26 & 20 & $0,30,60$ & $5,20^{3}$ & na & $S$ \\
\hline 7 & $\begin{array}{c}17 \text { and } 20 \\
\text { August } 2018\end{array}$ & 27 & 20 & $0,30,60$ & $12 \pm$ delay $^{3}$ & na & $F+1 d$ \\
\hline
\end{tabular}

${ }^{1}$ Graduate A+ fungicide (active ingredients $239 \mathrm{~g} \mathrm{~L}^{-1}$ azoxystrobin and $239 \mathrm{~g} \mathrm{~L}^{-1}$ fludioxonil; Syngenta Australia Pty Ltd, Macquarie Park, NSW, Australia.). No fungicide application is denoted as 'na'. ${ }^{2}$ Soft-ripe (S), firm-ripe (F) or one day after reaching firm-ripe $(\mathrm{F}+1 \mathrm{~d}) .{ }^{3}$ Refer to Section 2.3 for detailed explanation of postharvest cooling regimes.

In 2016, equal numbers of fruit were harvested from two (Experiment 1), three (Experiment 2) or four (Experiment 3) trees. Fruit were harvested from one tree for Experiment 8. The remaining experiments involved harvesting equal numbers of fruit from five trees. Fruits for Experiments 4 and 5 were from the same five trees. A different set of five trees in the same orchard provided the fruit 
used in Experiments 6 and 7. A randomised complete block (individual tree) design was used for Experiments 1 to 7 , and Experiment 8 was a completely randomised design.

Fruit dry matter was assessed to characterise fruit maturity at each harvest. Samples of five fruit per tree were assessed gravimetrically [10]. Approximately $5 \mathrm{~g}$ of mesocarp tissue was excised from the equatorial region of the fruit. Two rectangular segments of equal size and comprising inner, middle and outer mesocarp tissue were obtained from opposite sides of the fruit. The tissue was then sliced finely into $\sim 2 \mathrm{~mm}$ thick segments and weighed to the nearest $\mathrm{mg}$ into a tared aluminium dish of known mass. Samples were transferred to a $60{ }^{\circ} \mathrm{C}$ drying oven and repeatedly weighed at $24 \mathrm{~h}$ intervals until constant mass was achieved.

\subsection{Impact Treatments}

In a matched sampling approach, individual fruit were divided into $n$ groups of $k$ fruit according to their mass at harvest, where $n$ is the number of replicates and $k$ is the number of treatments. A single fruit, randomly selected from each group, was then assigned to each treatment. A single impact was applied to the equatorial region by placing the fruit in a swing-arm pendulum device and allowing it to fall from the prescribed height to strike against a rigid metal plate [11]. Rebound distance was recorded at the time of impact. Energy absorbed by the fruit was calculated using the following equation of Opara [11].

$$
\mathrm{AE}=\mathrm{m} \cdot \mathrm{g} \cdot\left(\mathrm{h}_{1}-\mathrm{h}_{2}\right)
$$

where, $\mathrm{AE}=$ absorbed energy $(\mathrm{J}), \mathrm{m}=$ fruit mass $(\mathrm{kg}), \mathrm{g}=$ acceleration due to gravity $\left(9.8 \mathrm{~m} \cdot \mathrm{s}^{-2}\right)$, $h_{1}=$ drop height $(m)$, and $h_{2}=$ rebound height $(m)$. The impact site was circled with a white paint pen. An arbitrarily chosen site of similar size and location was circled on non-impacted control fruit.

In Experiments 1-6, impact was applied to fruit at ambient temperature on the day of harvest. Half the fruit from Experiment 7 (prompt cooling treatment) and all the fruit from Experiment 8 were subjected to impact on the day following harvest, after fruit had been cooled to $12{ }^{\circ} \mathrm{C}$. The remaining half of the fruit from Experiment 7 were subjected to impact $4 \mathrm{~d}$ after harvest, after these fruit had cooled to $12{ }^{\circ} \mathrm{C}$.

\subsection{Temperature Treatments}

All fruit from Experiments 1-5 were held at $20^{\circ} \mathrm{C}$ for the period between impact treatment and disease assessment. In Experiment 6, fruit were held overnight at ambient conditions after receiving impact treatment. Half of the fruit from each drop height treatment were then held at $5{ }^{\circ} \mathrm{C}$, hereafter referred to as the 'cooling' treatment. The remaining fruit were held at $20^{\circ} \mathrm{C}$ for $24 \mathrm{~h}$, hereafter referred to as the 'no cooling' treatment. After $24 \mathrm{~h}$, the fruit were transferred to $5^{\circ} \mathrm{C}$, and subsequently subjected to the same conditions as fruit from the cooling treatment. The aim at this stage was to simulate the conditions likely to be encountered in a commercial domestic supply chain. These conditions were based on the best practice postharvest handling practices reported in the literature [12] and included ripening of fruit at $18{ }^{\circ} \mathrm{C}$ for $2 \mathrm{~d}$, followed by cooling to $5^{\circ} \mathrm{C}$ for subsequent dispatch. After $3 \mathrm{~d}$, retail display under ambient conditions was emulated by increasing the temperature to $20^{\circ} \mathrm{C}$. Air and fruit pulp temperature profiles for both treatments are presented (Figure 1a).

In Experiment 7, half the fruit were cooled to $12{ }^{\circ} \mathrm{C}$ on the day of harvest and subjected to impact treatment $24 \mathrm{~h}$ later, hereafter referred to as the 'prompt cooling' treatment. The remaining fruit were held at $22{ }^{\circ} \mathrm{C}$ for $48 \mathrm{~h}$, transferred to $12{ }^{\circ} \mathrm{C}$ for a further $48 \mathrm{~h}$ and then subjected to impact treatment, hereafter referred to as the 'delayed cooling' treatment. All fruit from Experiment 7 were transferred to $5{ }^{\circ} \mathrm{C}$ post-impact and subjected to the same conditions thereafter. Air and fruit pulp temperature profiles for both treatments are presented (Figure 1b). All fruit from Experiment 8 were subjected to the 'prompt cooling' postharvest temperature regime, as described for Experiment 7. 

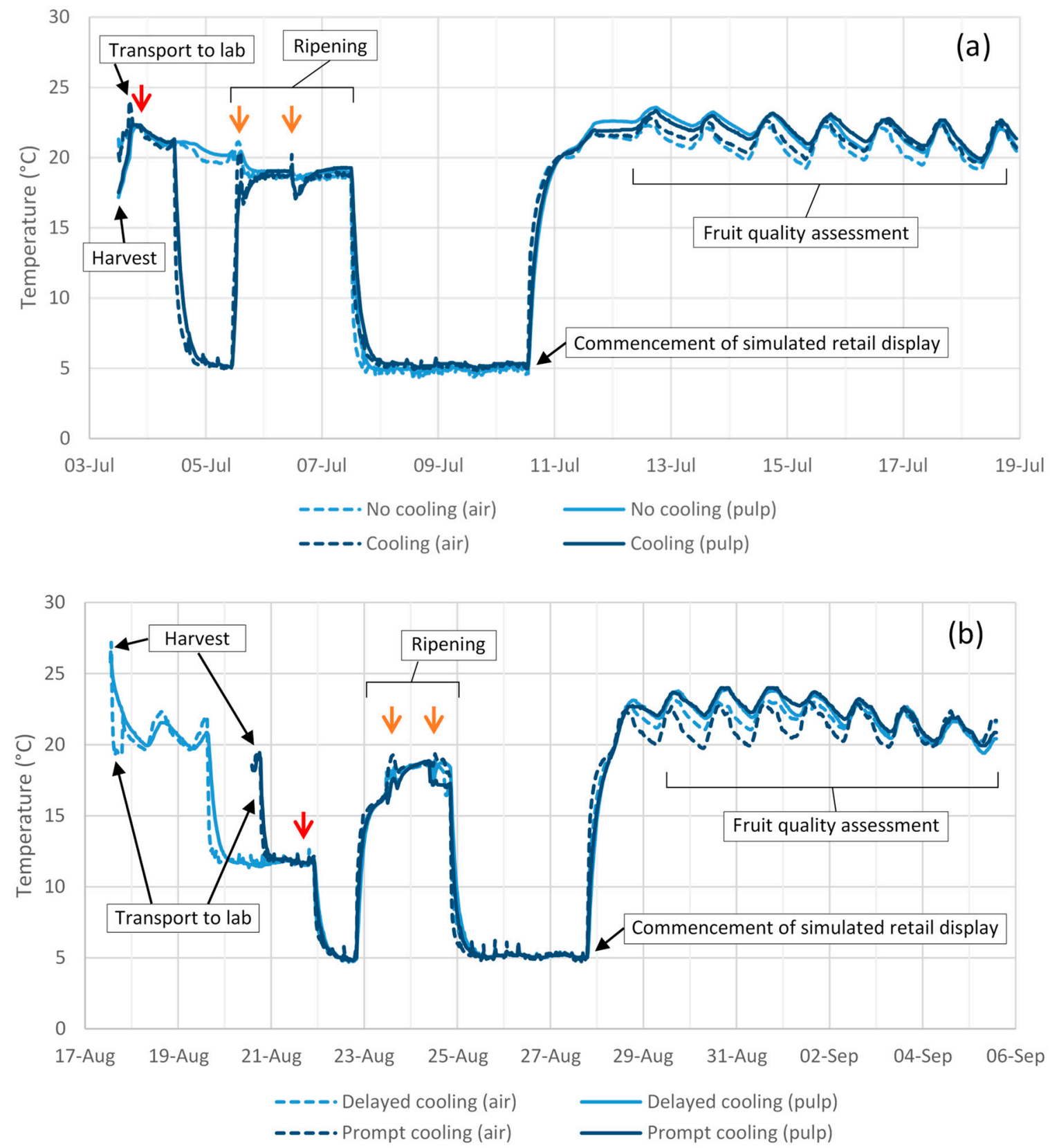

Figure 1. Air and fruit pulp temperature profiles for postharvest temperature treatments applied to 2018 season 'Hass' avocado fruit for (a) Experiment 6 and (b) Experiment 7. The red arrows indicate the time of impact treatment and the orange arrows indicate the time of ethephon application.

Temperature monitoring in Experiments 6 and 7 involved inserting the thermistor probe of a Tinytag Plus 2 data logger (TGP-4020; Gemini Data Loggers, West Sussex, UK) into one fruit from each of four trays (two per postharvest temperature treatment) to record pulp temperature at $30 \mathrm{~min}$ intervals. A Tinytag Plus 2 data logger with built-in sensors (TGP-4500; Gemini Data Loggers, West Sussex, UK) was placed in the centre of the same four trays of fruit to record air temperature at 30 min intervals.

\subsection{Fungicide Treatments}

In Experiment 8 only, all fruit received a $45 \mathrm{~s}$ dip in either water (control treatment) or a $2.5 \mathrm{~mL} \mathrm{~L}^{-1}$ solution of Graduate $\mathrm{A}+{ }^{\mathrm{TM}}$ fungicide (active ingredients $239 \mathrm{~g} \mathrm{~L}^{-1}$ azoxystrobin and $239 \mathrm{~g} \mathrm{~L}^{-1}$ fludioxonil; Syngenta Australia Pty Ltd, Macquarie Park, NSW, Australia) on the day after harvest. 
Fruit were removed from the $12{ }^{\circ} \mathrm{C}$ cold room for treatment, air dried on a bench at room temperature, re-packed carefully into trays and returned to the cold room within $3 \mathrm{~h}$. No fungicide was applied to fruit from other experiments.

\subsection{Ripening}

To promote uniform ripening, all fruit from all experiments were dipped for $15 \mathrm{~min}$ in a solution of $1000 \mu \mathrm{L} \mathrm{L}^{-1}$ Ethrel $^{\circledR}$ ethylene releasing agent $\left(720 \mathrm{~g} \mathrm{~L}^{-1}\right.$ ethephon; Bayer Crop Science Pty Ltd., East Hawthorn, VIC, Australia) along with 0.01\% polysorbate 20 (Tween ${ }^{\circledR} 20$; Sigma-Aldrich Pty Ltd, North Ryde, NSW, Australia) as a wetting agent. After ethephon treatment, fruit were air dried on a bench at room temperature before being carefully repacked into trays and returned to an appropriate temperature-controlled environment. For Experiments 1-5, dipping was conducted three times at $24 \mathrm{~h}$ intervals commencing on the day of harvest. This repeated application was found to give greater uniformity of ripening than a single application. For Experiment 6 , ripening treatment commenced $2 \mathrm{~d}$ after harvest and involved holding the fruit at $18{ }^{\circ} \mathrm{C}$ for $48 \mathrm{~h}$ and dipping the fruit on two occasions $24 \mathrm{~h}$ apart in that period (Figure 1a). Experiments 7 and 8 also used this ripening treatment, but it was commenced 3 or $6 \mathrm{~d}$ after harvest for fruit from prompt cooling and delayed cooling treatments, respectively (Figure $1 \mathrm{~b}$ ).

\subsection{Fruit Quality Assessment}

\subsubsection{Fruit Firmness}

Daily hand firmness evaluation commenced once fruit had completed the ripening treatment and been transferred to $20^{\circ} \mathrm{C}$ to simulate the environment encountered in retail stores and consumers' homes. Daily evaluation continued until the fruit had reached the designated ripeness stage for quality assessment. Firmness was rated according to the serial stages of hard, rubbery, sprung, softening, firm-ripe, soft-ripe, overripe and very overripe, as described by White et al. [13]. Objective firmness measurements were conducted once the fruit were considered to have reached the appropriate hand firmness stage. For Experiments 1 to 3, firmness was reported as Shore hardness ratings using a Turoni durometer with a spherical tip (model 53215TT; T.R. Turoni, Forli, Italy). For Experiments 4 to 8, a Sinclair Internal Quality Firmness Tester (Sinclair International Ltd., supplied by J Tech Systems, Albury, NSW, Australia), was used to measure firmness on an arbitrary scale from 0 (soft) to 100 (hard). This device has been shown to be a reliable, non-destructive tool for reflecting ripening avocado fruit firmness [14].

\subsubsection{Ripening Time and Weight Loss}

For 2018 season experiments, ripening time was calculated as the number of days between the first ethephon application and body rot assessment, rather than using harvest date as the base time. In this way, any confounding effect of the different harvest dates for prompt and delayed cooling treatments in Experiment 7 was eliminated. Fruit were weighed on the day of reaching the appropriate ripeness stage. Weight loss (\%) was calculated as the difference in mass between this measurement and the initial fruit mass on the day of harvest, expressed as a proportion (\%) of the initial fruit mass.

\subsubsection{Body Rots}

Assessment of body rots was conducted at soft-ripe stage in most experiments (Table 1). In Experiment 7, body rot assessment was conducted slightly earlier, at $1 \mathrm{~d}$ after reaching firm-ripe stage. This adjustment was to counteract the high propensity for rot development that fruit from these trees demonstrated in Experiment 6. In Experiment 3, where ripening stage was a treatment factor, half the fruit were assessed at firm-ripe stage and half at soft-ripe stage. Fruit were peeled, and the number of lesions occurring inside and outside the impact site were counted. Digital calipers were used to measure lesion diameter $(\mathrm{mm})$. Calculation of lesion area $\left(\mathrm{mm}^{2}\right)$ was based on the presumption that 
lesions are circular, which was generally found to be the case in this study. Areas of individual lesions were added to provide a total lesion area for inside and outside the impact site. Lesion area per fruit was calculated by adding these two values. Lesion incidence was reported as the number of fruit affected by body rot, expressed as a proportion (\%) of the total number of fruit in the sample.

\subsubsection{Mineral Nutrients}

Dried samples of fruit pulp, as used for dry matter determination in Experiments 6 and 7, were pooled to give a single sample per tree. Approximately $1.5 \mathrm{~g}$ of this dried tissue was ground to a fine powder using a coffee grinder. A sub-sample of $0.3 \mathrm{~g}$ was analysed for nitrogen $(\mathrm{N})$ using a LECO CN928 Carbon/Nitrogen combustion analyser (Leco, St Joseph, MI, USA). A further $0.3 \mathrm{~g}$ sub-sample was digested at $90^{\circ} \mathrm{C}$ in a mixture of $6 \mathrm{~mL}$ nitric acid and $2 \mathrm{~mL}$ perchloric acid using a technique adapted from Zasoski [15]. Once digestion was complete, the temperature was increased to $150{ }^{\circ} \mathrm{C}$ to evaporate the nitric acid. The remaining solution was cooled, made up to a final volume of $20 \mathrm{~mL}$ with deionised water and analysed for mineral nutrients using an inductively coupled plasma atomic emission spectrometer, as per the manufacturer's instructions (ICP-AES; Optima 7300 DV, Perkin Elmer; Wellesley, MA, USA).

\subsection{Pathogen Isolation and Identification}

At the end of Experiment 6, 10 fruit, representing two fruit from each of the five trees used in the study, were used for fungal isolations. Isolations were made from the margins of disease lesions. The tissue samples were plated onto potato dextrose agar (Difco ${ }^{\mathrm{TM}}$, Becton, Dickinson and Co., Franklin Lakes, NJ, USA) amended with streptomycin $(0.02 \%)$ (SPDA). The plates were incubated at $25^{\circ} \mathrm{C}$ for approximately $7 \mathrm{~d}$, and resultant colonies subcultured onto fresh SPDA. Fungal hyphae were scraped from 10 day old subcultures using a sterile plastic loop and macerated with $0.5 \mathrm{~mm}$ glass beads (Daintree Scientific, St Helens, TAS, Australia) in a Tissue Lyser (QIAGEN, Hilden, North Rhine-Westphalia, Germany). Genomic DNA was extracted using the BioSprint 15 DNA kit (QIAGEN) according to the manufacturers' instructions. Sequences were obtained from four gene regions for species identification: ITS (internal transcribed spacer), TUB ( $\beta$-tubulin 2), Cal (calmodulin) and GS (glutamine synthetase). Phusion ${ }^{\circledR}$ High-Fidelity PCR Mastermix (New England Biolabs, Ipswich, MA, USA) was used to amplify all gene regions. Purification and sequencing of PCR products was done by Macrogen Inc. (Seoul, South Korea) in a 3730xl DNA Analyser (Applied Biosystems, Foster City, CA, USA) using amplifying primers. Geneious bioinformatics software (Version 9.1; Biomatters, Auckland, NZ) was used to assemble all sequences that were generated. These sequences were compared against those from the GenBank nucleotide database using BLASTn (https://blast.ncbi.nlm.nih.gov/Blast.cgi) to confirm species identity, including a direct comparison with sequences from type specimens.

\subsection{Statistical Analysis}

Data were analysed using a general linear model analysis of variance in minitab ${ }^{\circledR}$, Version 17.3.1 (Minitab Pty Ltd., Sydney, Australia). The model included terms for each factor in the experiment (Table 1) and their interaction. Where significant differences were detected, means were compared using Fisher's least significant difference (LSD) test at a significance level of 0.05 . Linear regression was used to model the relationship between fruit size and energy absorbed upon impact. Non-linear regression was used to fit an asymptotic model to the relationship between disease incidence at the impact site and energy absorbed by the fruit upon impact.

\section{Results}

Absorbed energy is a measure of impact severity, and its magnitude is influenced by both drop height and fruit size, as shown by Equation (1). For each drop height, a linear relationship was found to exist between absorbed energy and fruit size (Figure 2). Between experiments, little difference in fruit size was found between fruit harvested in 2016 from Spring Creek and those harvested in 2017 
from Adare (Table 2). The mean mass of fruit harvested in 2018 from a different block of trees at Adare was at least $32 \%$ greater than that of fruit used in the earlier experiments. As a result, fruit from the 2018 season experiments were subjected to greater absorbed energy levels at a particular drop height than fruit from previous seasons' experiments (Table 2). The difference was most pronounced for the $60 \mathrm{~cm}$ drop height treatment, with the absorbed energy of fruit from the 2018 season being almost twice that of fruit from the 2016 season.

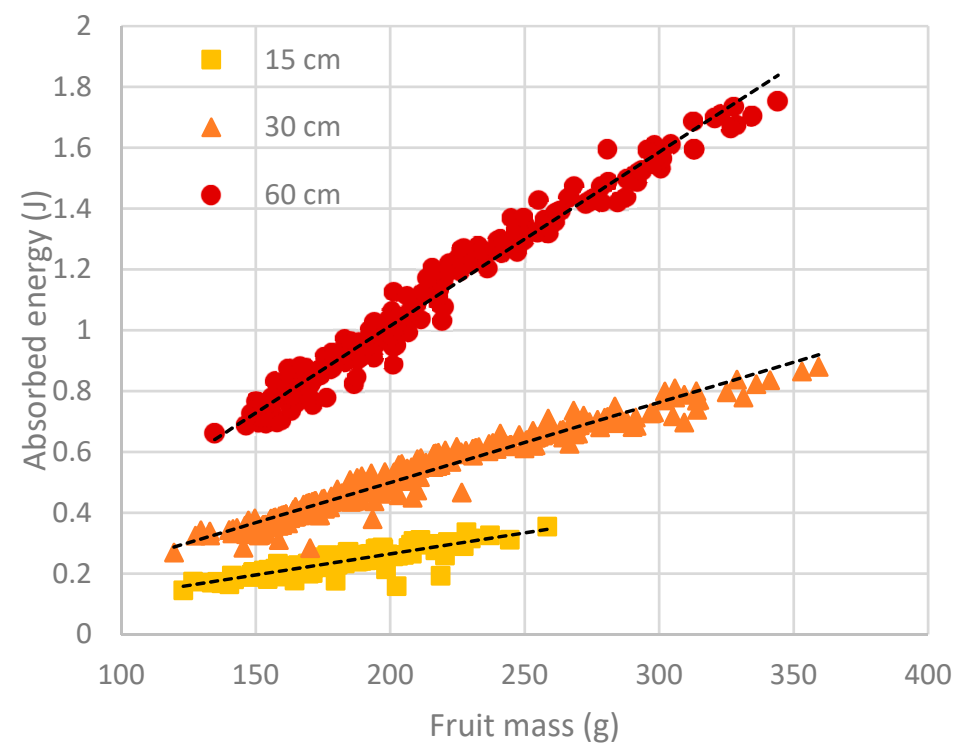

Figure 2. Relationship between fruit mass and energy absorbed by unripe 'Hass' avocado fruit upon impact from drop heights of $15(\square), 30(\Delta)$ or $60(\bullet) \mathrm{cm}$. Data points represent individual fruit values obtained from eight experiments. Dotted lines represent linear regression equations for $15 \mathrm{~cm}$ (absorbed energy $=-0.01147+0.001382$ fruit mass; $\left.\mathrm{R}^{2}=0.75 ; p<0.001 ; n=140\right), 30 \mathrm{~cm}$ (absorbed energy $=-0.03181$ +0.002645 fruit mass; $\mathrm{R}^{2}=0.96 ; p<0.001 ; n=300$ ) and $60 \mathrm{~cm}$ (absorbed energy $=-0.1290+0.005716$ fruit mass; $\mathrm{R}^{2}=0.97 ; p<0.001 ; n=190$ ) drop heights.

Table 2. Between-experiment comparison of fruit mass and energy absorbed by fruit upon impact from drop heights of 15,30 and $60 \mathrm{~cm}$.

\begin{tabular}{cccccc}
\hline \multirow{2}{*}{ Season } & \multirow{2}{*}{ Experiment } & \multirow{2}{*}{ Fruit Mass $\mathbf{( g )}$} & \multicolumn{3}{c}{ Absorbed Energy (J) } \\
\cline { 3 - 6 } & & & $\mathbf{1 5} \mathbf{~ \mathbf { ~ }}$ & $\mathbf{3 0} \mathbf{~ c m}$ & $\mathbf{6 0} \mathbf{~ c m}$ \\
\hline 2016 & 1 & $158 \mathrm{e}$ & $0.22 \mathrm{a}$ & $0.38 \mathrm{~d}$ & $0.75 \mathrm{c}$ \\
& 2 & $175 \mathrm{~d}$ & $0.24 \mathrm{a}$ & $0.46 \mathrm{c}$ & - \\
2017 & 3 & $164 \mathrm{e}$ & - & $0.41 \mathrm{~d}$ & - \\
& 4 & $179 \mathrm{~d}$ & $0.24 \mathrm{a}$ & $0.42 \mathrm{~cd}$ & $0.90 \mathrm{~b}$ \\
2018 & 5 & $178 \mathrm{~d}$ & $0.23 \mathrm{a}$ & $0.44 \mathrm{c}$ & $0.95 \mathrm{~b}$ \\
& 6 & $269 \mathrm{a}$ & - & $0.68 \mathrm{a}$ & $1.42 \mathrm{a}$ \\
& 7 & $256 \mathrm{~b}$ & - & $0.65 \mathrm{a}$ & $1.35 \mathrm{a}$ \\
& 8 & $236 \mathrm{c}$ & - & $0.61 \mathrm{~b}$ & - \\
\hline
\end{tabular}

${ }^{1}$ Drop heights not investigated are denoted by (-). Data were grouped across ripeness stages (Experiment 3), cooling treatments (Experiments 6 and 7) and fungicide treatments (Experiment 8). ${ }^{2}$ Means within a column that do not share a letter are significantly different $(p<0.05)$ according to Fisher's LSD test.

Despite these seasonal differences across years in fruit size and absorbed energy, disease incidence in response to impact was similar between experiments. At soft-ripe stage, disease incidence generally increased with increasing drop height (Table 3). Disease incidence did not exceed $40 \%$ in fruit subjected to no impact, whereas impact from a drop height of $30 \mathrm{~cm}$ caused a two- to eight-fold increase in disease incidence as compared with non-impacted fruit. A nonlinear relationship was observed to exist between disease incidence at the impact site and the energy absorbed by the fruit upon impact 
(Figure 3). Modelling of the relationship suggested that an absorbed energy of $0.54 \mathrm{~J}$ (roughly equivalent to dropping a $220 \mathrm{~g}$ fruit from a height of $30 \mathrm{~cm}$ ) is sufficient to cause two out of every three fruit to express body rots at soft-ripe stage. Body rots were rarely observed in fruit assessed at firm-ripe stage in Experiment 3. Although flesh bruising was not the focus of this study, it was noted that no flesh bruising was apparent in any of the fruit subjected to impact.

Table 3. Disease incidence at the impact site in 'Hass' avocado fruit dropped from a height of 0, 15, 30 or $60 \mathrm{~cm}$ on the day of harvest ${ }^{1}$ and assessed at soft-ripe stage (S), firm-ripe stage (F) or 1 day after reaching firm-ripe stage $(\mathrm{F}+1 \mathrm{~d})$.

\begin{tabular}{|c|c|c|c|c|c|c|c|}
\hline \multirow{2}{*}{ Season } & \multirow{2}{*}{ Experiment } & \multirow{2}{*}{$\begin{array}{l}\text { Ripeness } \\
\text { Stage }\end{array}$} & \multirow{2}{*}{$\begin{array}{l}\text { Fruit Firmness } \\
\text { at Assessment }\end{array}$} & \multicolumn{4}{|c|}{ Disease Incidence at Impact Site (\%) } \\
\hline & & & & $0 \mathrm{~cm}$ & $15 \mathrm{~cm}$ & $30 \mathrm{~cm}$ & $60 \mathrm{~cm}$ \\
\hline \multirow[t]{4}{*}{2016} & 1 & S & $34.9 \pm 0.3^{3}$ & 10 & 0 & 70 & 90 \\
\hline & 2 & $S$ & $34.5 \pm 0.3^{3}$ & 13 & 20 & 73 & - \\
\hline & 3 & $\mathrm{~F}$ & $50.3 \pm 0.3^{3}$ & 3 & - & 5 & - \\
\hline & 3 & S & $35.0 \pm 0.3^{3}$ & 10 & - & 80 & - \\
\hline \multirow[t]{2}{*}{2017} & 4 & $S$ & $10.4 \pm 0.2^{4}$ & 24 & 38 & 62 & 88 \\
\hline & 5 & S & $11.4 \pm 0.1^{4}$ & 14 & 52 & 48 & 70 \\
\hline \multirow[t]{3}{*}{2018} & 6 & $S$ & $10.6 \pm 0.2^{4}$ & 40 & - & 78 & 83 \\
\hline & 7 & $F+1 d$ & $12.2 \pm 0.2^{4}$ & 20 & - & 70 & 79 \\
\hline & 8 & $S$ & $10.4 \pm 0.2^{4}$ & 23 & - & 90 & - \\
\hline
\end{tabular}

${ }^{1}$ Fruit from Experiment 7 were dropped at time of packing, $1-4 \mathrm{~d}$ after harvest. ${ }^{2}$ For $0 \mathrm{~cm}$ drop height treatments, data were collected from an arbitrarily selected site of similar size and location on the fruit as the impact site in other treatments. Drop heights not investigated are denoted by (-). Data were grouped across cooling treatments (Experiments 6 and 7) and fungicide treatments (Experiment 8$).{ }^{3}$ Shore hardness rating ( \pm s.e.) as measured using a Turoni durometer with a spherical tip. ${ }^{4}$ Arbitrary units ( \pm s.e.) as measured using a Sinclair Internal Quality Firmness Tester.

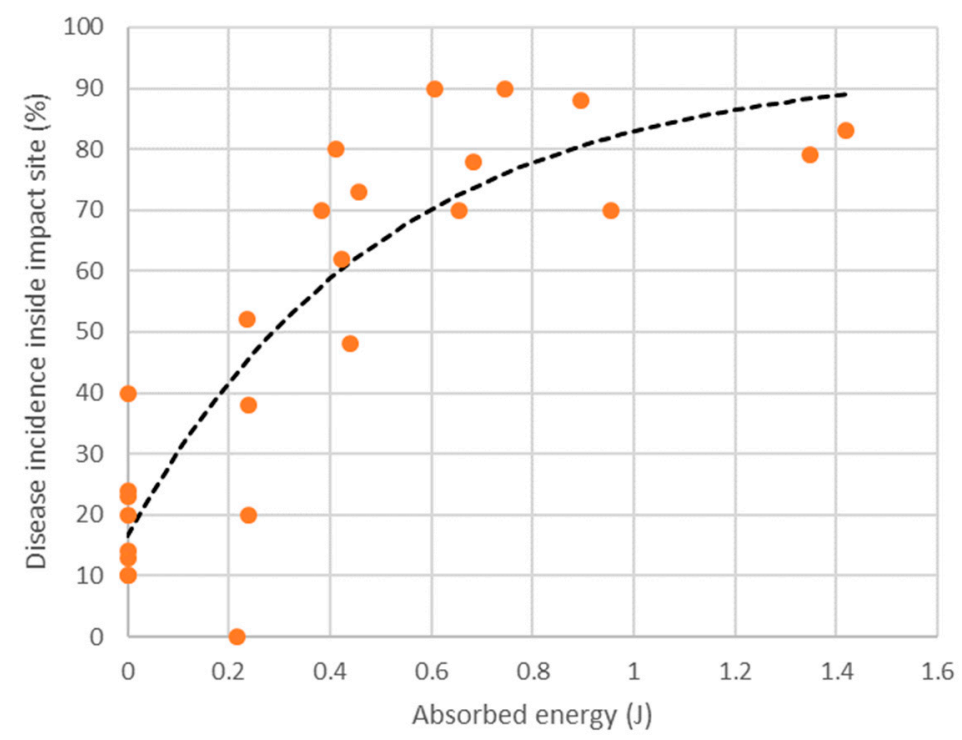

Figure 3. Relationship between disease incidence inside the impact site at soft-ripe stage and energy absorbed by unripe 'Hass' avocado fruit upon impact. Data points represent mean values for each drop height treatment and were obtained from eight experiments. Dotted line represents a nonlinear asymptotic regression equation (disease incidence proportion $=0.936176-0.771635 \times \exp (-1.98249 \times$ absorbed energy); $S=0.15$; lack-of-fit $p=0.075 ; n=25$ ), in which disease incidence proportion has been converted to a percentage.

Experiments conducted in 2016 on fruit from the Spring Creek orchard revealed that impact from 30 or $60 \mathrm{~cm}$, but not $15 \mathrm{~cm}$, induced more lesions at the impact site than occurred in a similarly sized and located site arbitrarily marked on non-impacted fruit on the day of harvest (Tables 4 and 5). Lesion 
area at the impact site was seven to nine times greater in fruit dropped $30 \mathrm{~cm}$ than in non-impacted fruit. A $60 \mathrm{~cm}$ drop height caused the lesion area at the impact site to be 15 times higher than in non-impacted fruit.

Table 4. Lesion number and lesion area inside the impact site, outside the impact site and for the whole fruit in 2016 season 'Hass' avocado fruit dropped from varying heights on the day of harvest in Experiments 1 and 2, and assessed at soft-ripe stage.

\begin{tabular}{|c|c|c|c|c|c|c|}
\hline \multirow[b]{2}{*}{ Drop Height } & \multicolumn{3}{|c|}{ No. Lesions ${ }^{1}$} & \multicolumn{3}{|c|}{ Lesion Area $\left(\mathrm{mm}^{2}\right)^{1}$} \\
\hline & $\begin{array}{c}\text { Inside } \\
\text { Impact Site }\end{array}$ & $\begin{array}{c}\text { Outside } \\
\text { Impact Site }\end{array}$ & $\begin{array}{l}\text { Whole } \\
\text { Fruit }\end{array}$ & $\begin{array}{c}\text { Inside } \\
\text { Impact Site }\end{array}$ & $\begin{array}{c}\text { Outside } \\
\text { Impact Site }\end{array}$ & $\begin{array}{l}\text { Whole } \\
\text { Fruit }\end{array}$ \\
\hline \multicolumn{7}{|l|}{ Experiment 1} \\
\hline $0 \mathrm{~cm}$ & $0.1 \mathrm{c}$ & $0.0 \mathrm{a}$ & $0.1 \mathrm{c}$ & $67 c$ & $0 \mathrm{a}$ & $67 c$ \\
\hline $15 \mathrm{~cm}$ & $0.0 \mathrm{c}$ & $0.1 \mathrm{a}$ & $0.1 \mathrm{c}$ & $0 \mathrm{c}$ & $20 \mathrm{a}$ & $20 c$ \\
\hline $30 \mathrm{~cm}$ & $0.8 \mathrm{~b}$ & $0.0 \mathrm{a}$ & $0.8 \mathrm{~b}$ & $494 \mathrm{~b}$ & $0 \mathrm{a}$ & $494 \mathrm{~b}$ \\
\hline $60 \mathrm{~cm}$ & $1.4 \mathrm{a}$ & $0.0 \mathrm{a}$ & $1.4 \mathrm{a}$ & 1016 a & $0 \mathrm{a}$ & 1016 a \\
\hline \multicolumn{7}{|l|}{ Experiment 2} \\
\hline $0 \mathrm{~cm}$ & $0.1 \mathrm{~b}$ & $0.0 \mathrm{a}$ & $0.1 \mathrm{~b}$ & $74 \mathrm{~b}$ & $0 \mathrm{a}$ & $74 \mathrm{~b}$ \\
\hline $15 \mathrm{~cm}$ & $0.2 \mathrm{~b}$ & $0.0 \mathrm{a}$ & $0.2 \mathrm{~b}$ & $97 \mathrm{~b}$ & $0 \mathrm{a}$ & $97 \mathrm{~b}$ \\
\hline $30 \mathrm{~cm}$ & $1.1 \mathrm{a}$ & $0.0 \mathrm{a}$ & $1.1 \mathrm{a}$ & $583 \mathrm{a}$ & $0 \mathrm{a}$ & $583 \mathrm{a}$ \\
\hline
\end{tabular}

${ }^{1}$ Means within a column and experiment that do not share a letter are significantly different $(p<0.05)$ according to Fisher's LSD test.

Table 5. Lesion number and lesion area inside the impact site, outside the impact site and for the whole fruit in 2016 season 'Hass' avocado fruit dropped from 0 or $30 \mathrm{~cm}$ on the day of harvest in Experiment 3 and assessed at firm-ripe or soft-ripe stage.

\begin{tabular}{|c|c|c|c|c|c|c|}
\hline \multirow[b]{2}{*}{ Treatment Factor } & \multicolumn{3}{|c|}{ No. Lesions ${ }^{1}$} & \multicolumn{3}{|c|}{ Lesion Area $\left(\mathrm{mm}^{2}\right)^{1}$} \\
\hline & $\begin{array}{c}\text { Inside } \\
\text { Impact Site }\end{array}$ & $\begin{array}{c}\text { Outside } \\
\text { Impact Site }\end{array}$ & $\begin{array}{l}\text { Whole } \\
\text { Fruit }\end{array}$ & $\begin{array}{c}\text { Inside } \\
\text { Impact Site }\end{array}$ & $\begin{array}{c}\text { Outside } \\
\text { Impact Site }\end{array}$ & $\begin{array}{c}\text { Whole } \\
\text { Fruit }\end{array}$ \\
\hline \multicolumn{7}{|l|}{ Drop height (D) } \\
\hline $0 \mathrm{~cm}$ & $0.06 \mathrm{~b}$ & $0.00 \mathrm{a}$ & $0.06 \mathrm{~b}$ & $49 \mathrm{~b}$ & $0 \mathrm{a}$ & $49 \mathrm{~b}$ \\
\hline $30 \mathrm{~cm}$ & $0.69 \mathrm{a}$ & $0.04 \mathrm{a}$ & $0.73 \mathrm{a}$ & $376 \mathrm{a}$ & $10 \mathrm{a}$ & $387 \mathrm{a}$ \\
\hline \multicolumn{7}{|l|}{ Ripeness stage (R) } \\
\hline Firm-ripe & $0.04 \mathrm{~b}$ & $0.00 \mathrm{a}$ & $0.04 \mathrm{~b}$ & $26 \mathrm{~b}$ & $0 \mathrm{a}$ & $26 \mathrm{~b}$ \\
\hline Soft-ripe & $0.71 \mathrm{a}$ & $0.04 \mathrm{a}$ & $0.75 \mathrm{a}$ & 400 a & $10 \mathrm{a}$ & $410 \mathrm{a}$ \\
\hline \multicolumn{7}{|l|}{$\mathbf{D} \times \mathbf{R}$} \\
\hline $0 \mathrm{~cm}$, firm-ripe & $0.03 \mathrm{~b}$ & $0.00 \mathrm{a}$ & $0.03 \mathrm{~b}$ & $18 \mathrm{~b}$ & $0 \mathrm{a}$ & $18 \mathrm{~b}$ \\
\hline $30 \mathrm{~cm}$, firm-ripe & $0.05 \mathrm{~b}$ & $0.00 \mathrm{a}$ & $0.05 \mathrm{~b}$ & $33 \mathrm{~b}$ & $0 \mathrm{a}$ & $33 \mathrm{~b}$ \\
\hline $0 \mathrm{~cm}$, soft-ripe & $0.10 \mathrm{~b}$ & $0.00 \mathrm{a}$ & $0.10 \mathrm{~b}$ & $80 \mathrm{~b}$ & $0 \mathrm{a}$ & $80 \mathrm{~b}$ \\
\hline $30 \mathrm{~cm}$, soft-ripe & $1.33 \mathrm{a}$ & $0.08 \mathrm{a}$ & $1.40 \mathrm{a}$ & $720 \mathrm{a}$ & $20 \mathrm{a}$ & $740 \mathrm{a}$ \\
\hline \multicolumn{7}{|l|}{ p value } \\
\hline Drop height (D) & $* * *$ & ns & $* * *$ & $* * *$ & ns & $* * *$ \\
\hline Ripeness stage (R) & $* * *$ & ns & $* * *$ & $* * *$ & ns & $* * *$ \\
\hline $\mathrm{D} \times \mathrm{R}$ & $* * *$ & ns & $* * *$ & $* * *$ & ns & $* * *$ \\
\hline
\end{tabular}

${ }^{1}$ Means within a column and treatment factor that do not share a letter are significantly different $(p<0.05)$ according to Fisher's LSD test. ns not significant; ${ }^{* *} p<0.001$.

Body rot development elsewhere on the fruit was almost non-existent for all treatments and, therefore, disease expression at a 'whole fruit' level was determined solely by the occurrence of body rots at the impact site. Fruit dropped $30 \mathrm{~cm}$ had substantially fewer lesions and a smaller lesion area at firm-ripe stage than soft-ripe stage, whereas non-impacted fruit had a similarly low lesion number and area at both ripeness stages (Table 5). 
Experiments conducted in 2017 also showed a trend of increasing lesion number and area at the impact site as drop height increased (Figures 4 and 5a,b). In Experiment 4, a drop height of $30 \mathrm{~cm}$ was sufficient to produce more lesions, and more than twice the lesion area at the impact site than occurred at a similar-sized site marked on non-impacted fruit (Figure 5a). When the experiment was repeated on fruit harvested from the same trees five weeks later (Experiment 5), fruit dropped $30 \mathrm{~cm}$ had a lesion area at the impact site that was eleven times greater than that observed in non-impacted fruit (Figure $5 \mathrm{~b}$ ). Furthermore, a drop height of $15 \mathrm{~cm}$ produced more lesions, but not a larger lesion area, at the impact site than occurred in non-impacted fruit.
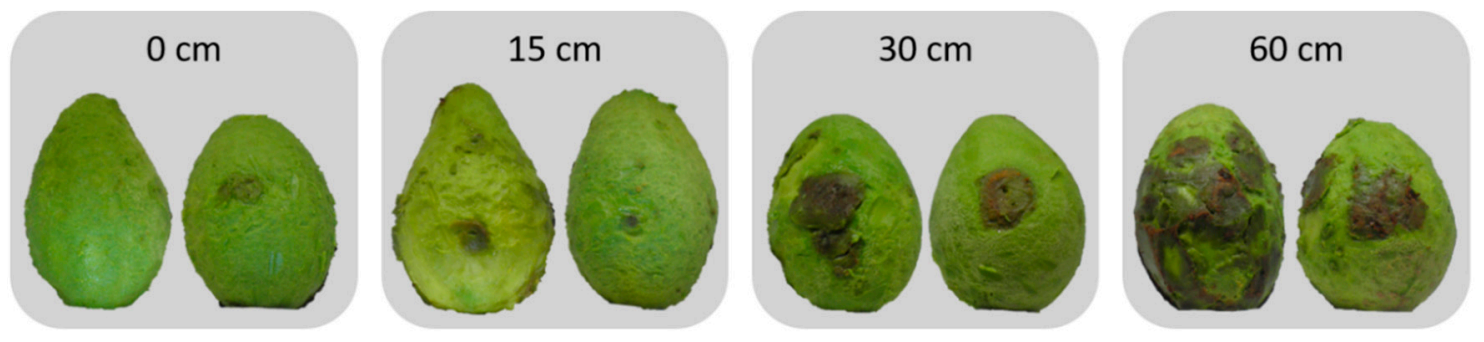

Figure 4. Body rot expression in 2017 season 'Hass' avocado fruit dropped 0, 15, 30 or $60 \mathrm{~cm}$ on the day of harvest in Experiment 5 and assessed at soft-ripe stage.

In both 2017 season experiments, body rots also developed outside the impact site and generally increased in number and/or area as fruit were dropped from greater heights (Figure 5c,d). At least one of these responses differed significantly between non-impacted fruit and those dropped $30 \mathrm{or} 60 \mathrm{~cm}$, but not $15 \mathrm{~cm}$. Within a treatment, lesions elsewhere on the fruit did not appear to be as numerous or extensive as those observed at the impact site. Hence, treatment differences in body rot expression at a 'whole fruit' level (Figure 5e,f) largely reflected those found at the impact site.

In 2018 season experiments, disease expression in response to impact was generally consistent with previous seasons' findings (Figures 6-8). For Experiment 6, impact at harvest resulted in mean lesion areas at the impact site that were seven to 19 times larger than those observed in non-impacted fruit from the same cooling treatment (Figure $6 \mathrm{~b}$ ). Irrespective of cooling treatment, lesion area at the impact site almost doubled as drop height increased from 30 to $60 \mathrm{~cm}$, despite no associated increase in lesion number (Figure 6a). Fruit subjected to a $60 \mathrm{~cm}$ drop height followed by cooling to $5{ }^{\circ} \mathrm{C}$ displayed a larger lesion area at the impact site than did fruit from any other treatment. Many fruit in this experiment displayed extensive body rot development, causing lesions to coalesce and to cover the entire fruit surface in some cases. As a result, lesion area at the impact site could only be accurately measured for 108 of the 120 fruit sampled and no data were collected for lesions occurring outside the impact site.

Body rot assessment in Experiment 7 was conducted earlier, at $1 \mathrm{~d}$ after reaching firm-ripe stage, than it had been for Experiment 6, at soft-ripe stage. Doing so enabled a more accurate measurement of lesions, as they tended to be smaller and less numerous than in Experiment 6. Postharvest temperature regime in Experiment 7 had no influence on body rot expression in non-impacted fruit or fruit dropped $30 \mathrm{~cm}$ (Figures 7 and 8). For fruit dropped $60 \mathrm{~cm}$, prompt as opposed to delayed cooling resulted in twice as many lesions occurring outside the impact site (Figure 8c). The total area of these lesions was 2.5 times higher in fruit that received prompt cooling (Figure 8d). 

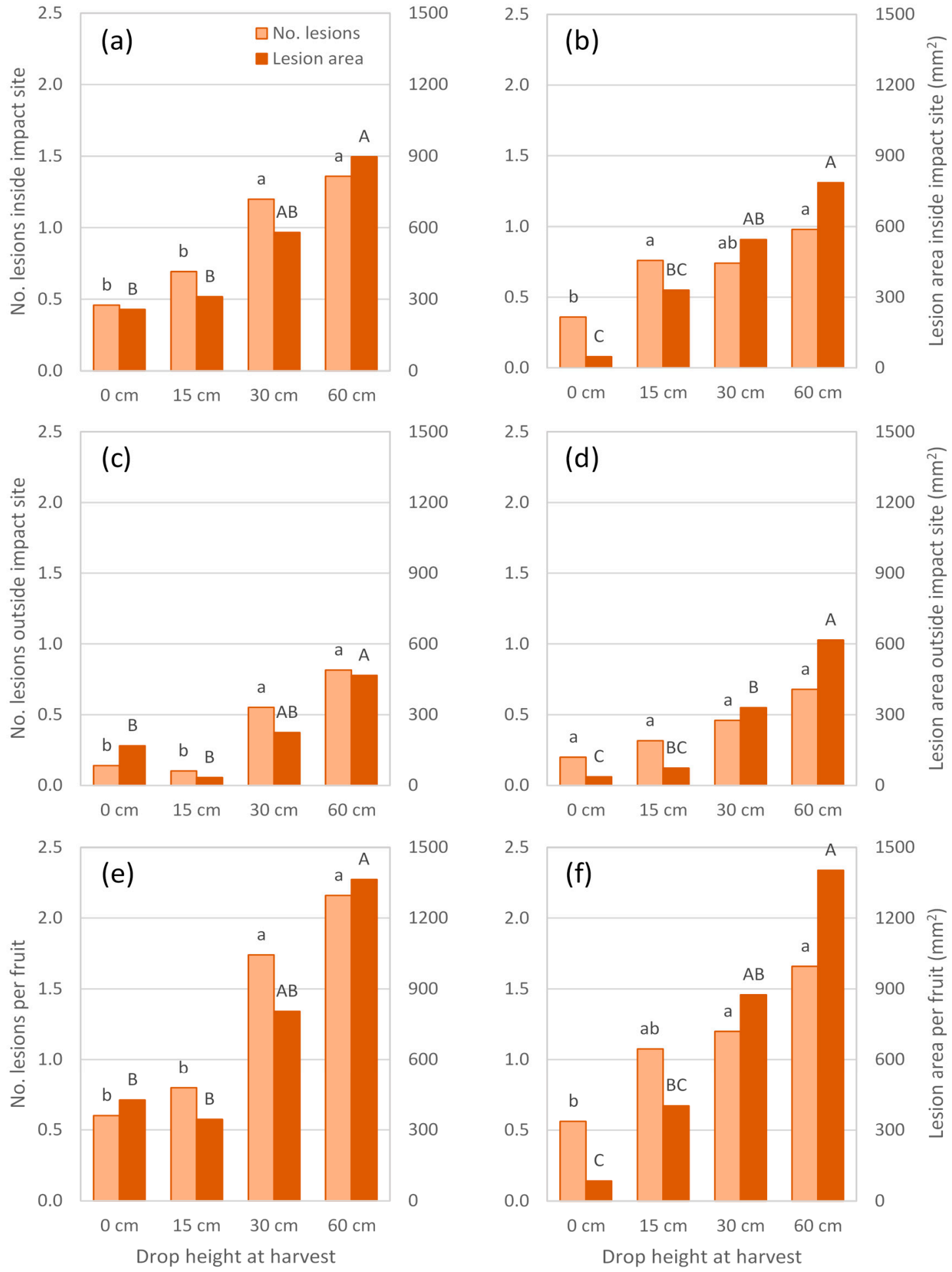

Figure 5. Lesion number and lesion area inside the impact site $(\mathbf{a}, \mathbf{b})$, outside the impact site (c,d) and for the whole fruit (e,f) in 2017 season 'Hass' avocado fruit dropped 0, 15, 30 or $60 \mathrm{~cm}$ on the day of harvest in Experiment $4(\mathbf{a}, \mathbf{c}, \mathbf{e})$ and Experiment $5(\mathbf{b}, \mathbf{d}, \mathbf{f})$ and assessed at soft-ripe stage. Means that do not share a letter (lowercase for lesion number, uppercase for lesion area) are significantly different $(p<$ $0.05)$ according to Fisher's LSD test. 

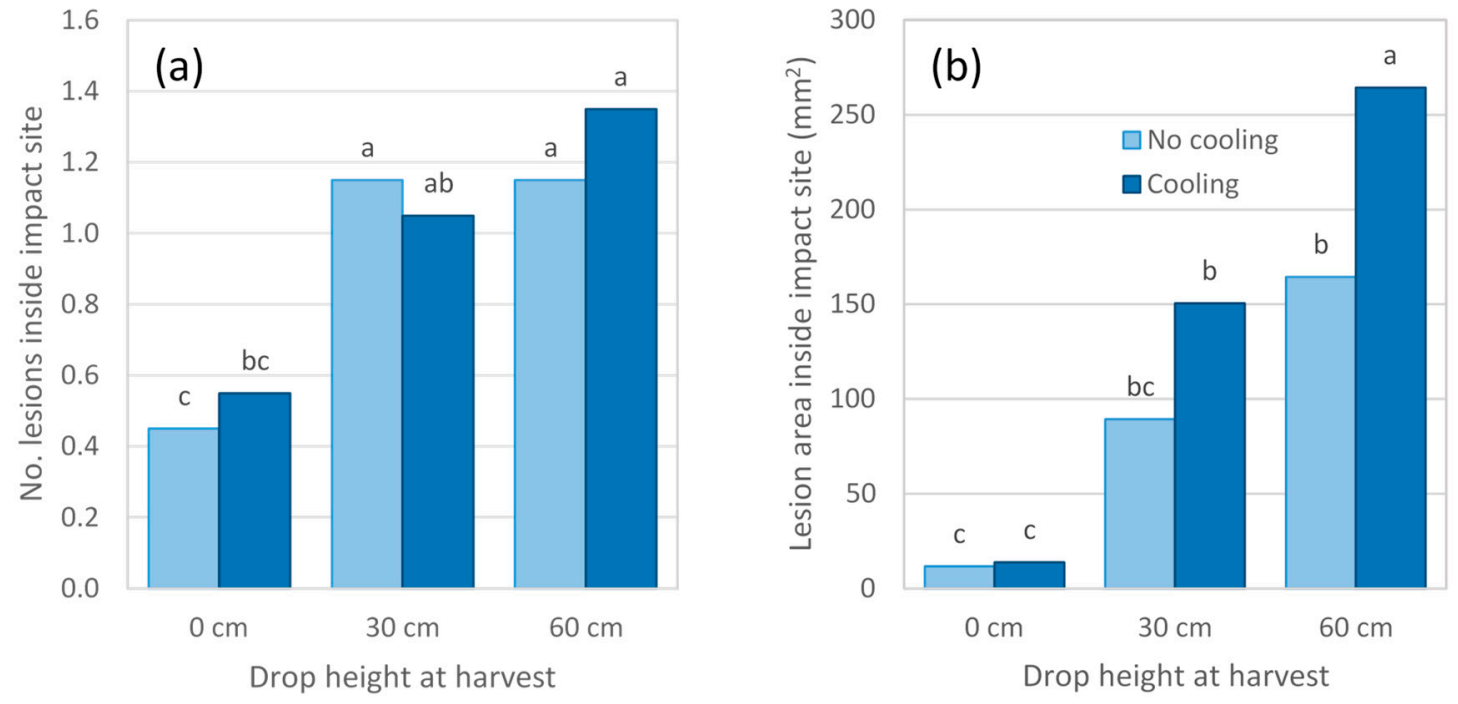

Figure 6. Lesion number (a) and lesion area (b) inside the impact site in 'Hass' avocado fruit from Experiment 6 assessed at soft-ripe stage. Fruit were subjected to drop heights of $0,30 \mathrm{or} 60 \mathrm{~cm}$ on day of harvest, held overnight at ambient conditions and either cooled to $5{ }^{\circ} \mathrm{C}$ (cooling) or held at $20{ }^{\circ} \mathrm{C}$ (no cooling) for $24 \mathrm{~h}$ prior to ripening. Means that do not share a letter are significantly different $(p<0.05)$ according to Fisher's LSD test.

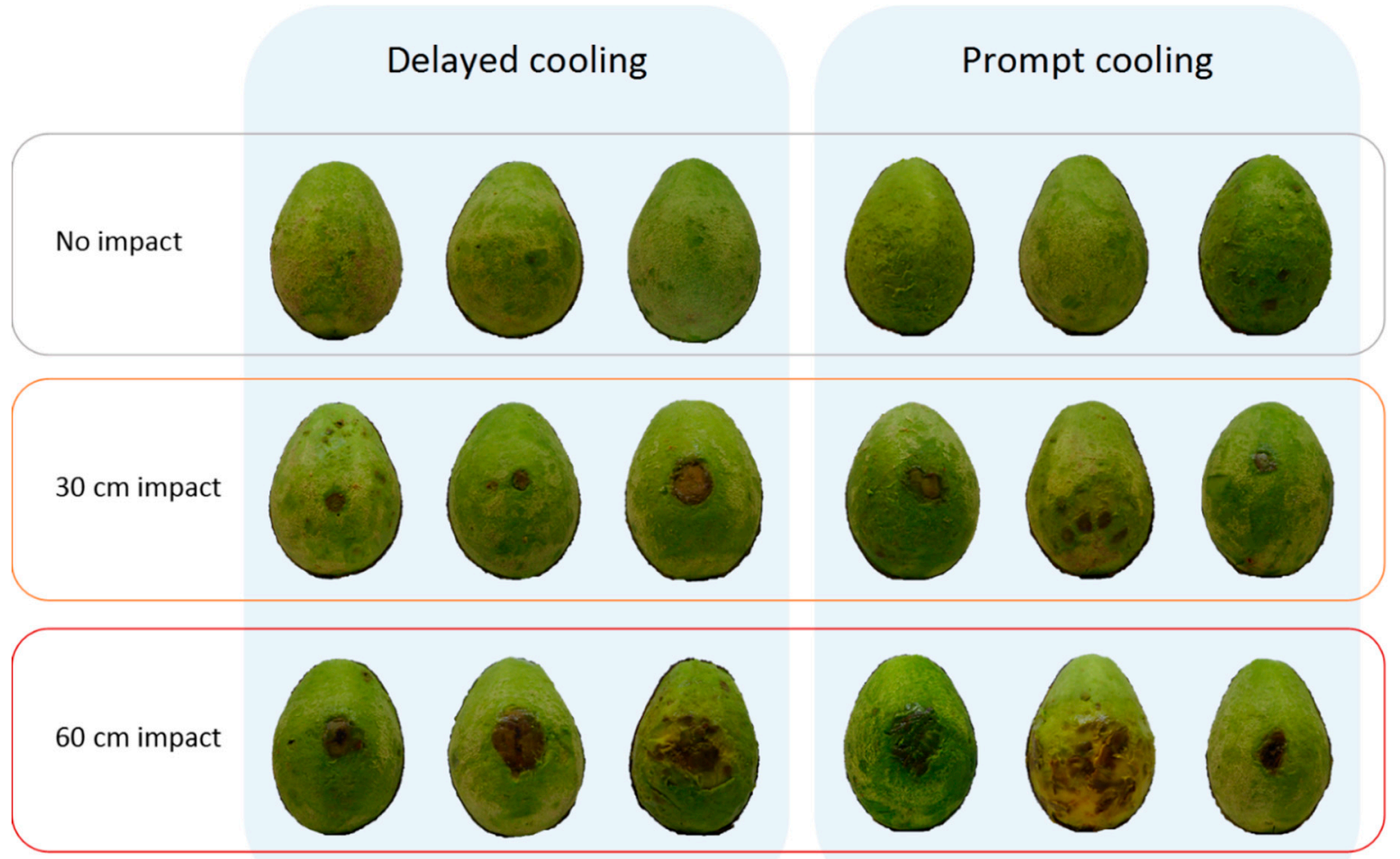

Figure 7. Body rot expression in 'Hass' avocado fruit from Experiment 7 at $1 \mathrm{~d}$ after reaching firm-ripe stage. Fruit were harvested on 17 and 20 August 2018 and subjected to drop heights of 0,30 or $60 \mathrm{~cm}$ on 21 August 2018. Fruit from the first harvest were held at ambient conditions for $48 \mathrm{~h}$ followed by $48 \mathrm{~h}$ at $12{ }^{\circ} \mathrm{C}$ (delayed cooling). Fruit from the second harvest were cooled to $12{ }^{\circ} \mathrm{C}$ on the day of harvest (prompt cooling). 

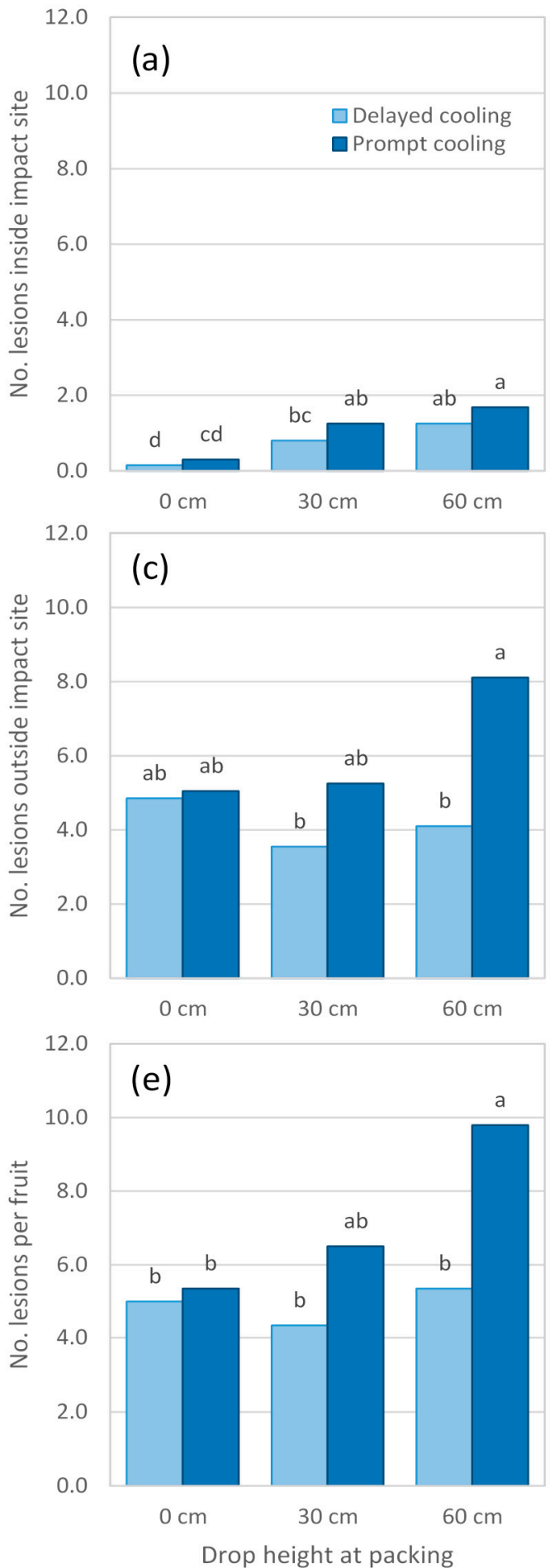
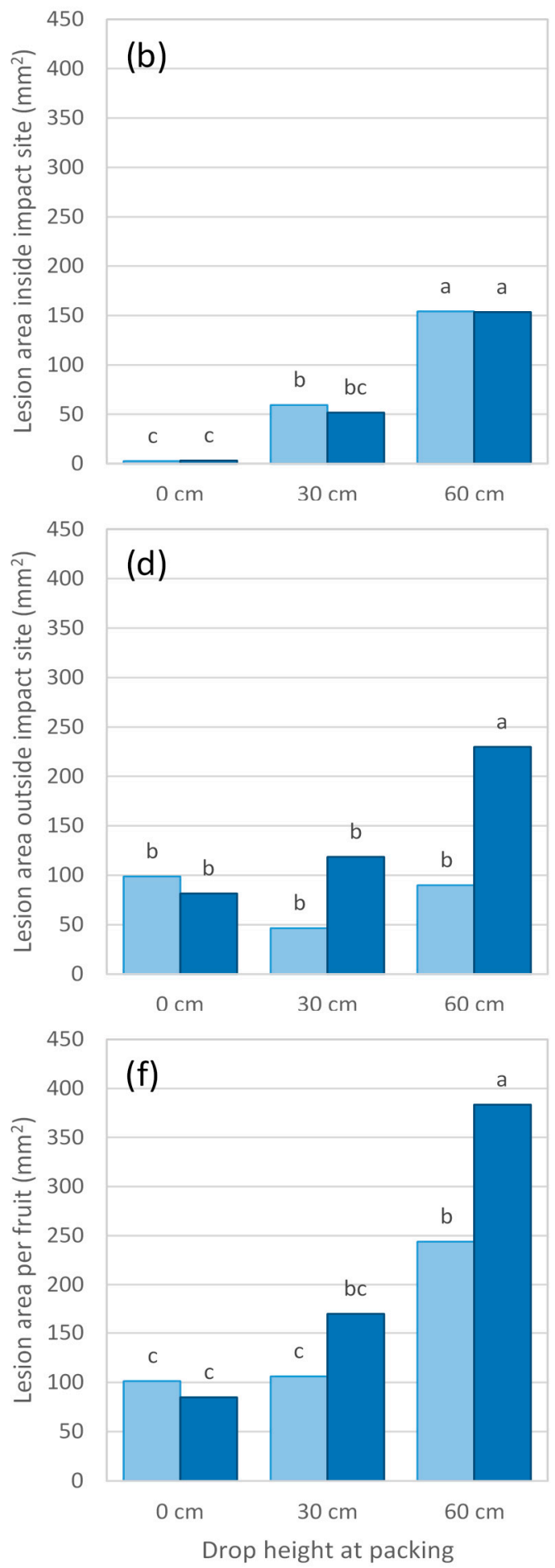

Figure 8. Lesion number $(\mathbf{a}, \mathbf{c}, \mathbf{e})$ and lesion area $(\mathbf{b}, \mathbf{d}, \mathbf{f})$ inside the impact site $(\mathbf{a}, \mathbf{b})$, outside the impact site $(\mathbf{c}, \mathbf{d})$ and for the whole fruit $(\mathbf{e}, \mathbf{f})$ in 'Hass' avocado fruit from Experiment 7 at $1 \mathrm{~d}$ after reaching firm-ripe stage. Fruit were harvested on 17 or 20 August 2018 and subjected to drop heights of 0,30 or $60 \mathrm{~cm}$ on 21 August 2018. Fruit from the first harvest were held at ambient conditions for $48 \mathrm{~h}$ followed by $48 \mathrm{~h}$ at $12{ }^{\circ} \mathrm{C}$ (delayed cooling). Fruit from the second harvest were cooled to $12{ }^{\circ} \mathrm{C}$ on the day of harvest (prompt cooling). Means that do not share a letter are significantly different $(p<0.05)$ according to Fisher's LSD test. 
Experiment 7 also showed that increasing impact severity caused more lesions and a larger lesion area at the impact site (Figure $8 \mathrm{a}, \mathrm{b}$ ). These findings were similar to those of previous experiments, despite disease assessment being conducted at a slightly earlier ripeness stage. In all treatments, relatively more body rots occurred outside the impact site than inside it. These rots were randomly distributed across the fruit surface and did not appear to be more concentrated towards the impact site. Fruit subjected to prompt cooling and a $60 \mathrm{~cm}$ drop height had more lesions outside the impact site and almost three times the lesion area than found outside the impact site in promptly cooled, non-impacted fruit. This finding suggests that impact can trigger disease expression elsewhere on the fruit, not only at the site of impact. At a 'whole fruit' level, the number of lesions was largely driven by body rots outside the impact site (Figure 8e), whereas body rots occurring inside and outside the impact site both substantially contributed to the overall lesion area (Figure 8f). Hence, a drop height of $60 \mathrm{~cm}$ produced larger lesion areas per fruit than were found in any other impact treatment, and the response was greater for promptly cooled fruit.

No differences in fruit weight loss were observed between treatments in Experiment 6 or 7 (Table 6). Ripening time in these experiments was not affected by impact treatment, but was $\sim 1 \mathrm{~d}$ longer in fruit that received prompt as opposed to delayed cooling in Experiment 7 and in cooled as opposed to uncooled fruit subjected to a $60 \mathrm{~cm}$ drop height in Experiment 6 (Table 6).

Table 6. Ripening time and weight loss of 2018 season 'Hass' avocado fruit from Experiments 6 and 7 , subjected to drop heights of 0,30 and $60 \mathrm{~cm}$. Fruit were considered 'ripe' at soft-ripe stage for Experiment 6 and $1 \mathrm{~d}$ after firm-ripe stage for Experiment 7.

\begin{tabular}{ccccccc}
\hline \multirow{2}{*}{ Postharvest Cooling Treatment } & \multicolumn{3}{c}{ Ripening Time (d) } & \multicolumn{3}{c}{ Weight Loss (\%) ${ }^{\mathbf{1}}$} \\
\cline { 2 - 7 } & $\mathbf{0 ~} \mathbf{~ c m}$ & $\mathbf{3 0} \mathbf{~ c m}$ & $\mathbf{6 0} \mathbf{~ c m}$ & $\mathbf{0} \mathbf{~ c m}$ & $\mathbf{3 0} \mathbf{~ c m}$ & $\mathbf{6 0} \mathbf{~ c m}$ \\
\hline Experiment 6 & & & & & & \\
No cooling & $10.9 \mathrm{~b}$ & $11.0 \mathrm{~b}$ & $10.7 \mathrm{~b}$ & $6.8 \mathrm{a}$ & $7.1 \mathrm{a}$ & $7.0 \mathrm{a}$ \\
Cooling & $11.4 \mathrm{ab}$ & $11.3 \mathrm{ab}$ & $11.8 \mathrm{a}$ & $6.9 \mathrm{a}$ & $7.0 \mathrm{a}$ & $7.6 \mathrm{a}$ \\
\hline Experiment 7 & & & & & & \\
Delayed cooling & $8.7 \mathrm{~cd}$ & $8.5 \mathrm{~cd}$ & $8.3 \mathrm{~d}$ & $6.3 \mathrm{a}$ & $6.2 \mathrm{a}$ & $6.0 \mathrm{a}$ \\
Prompt cooling & $9.8 \mathrm{ab}$ & $10.0 \mathrm{a}$ & $9.2 \mathrm{bc}$ & $6.4 \mathrm{a}$ & $6.7 \mathrm{a}$ & $6.3 \mathrm{a}$ \\
\hline
\end{tabular}

${ }^{1}$ Number of days between first ethephon dip and body rot assessment. ${ }^{2}$ Means within an experiment that do not share a letter are significantly different $(p<0.05)$ according to Fisher's LSD test.

Mineral nutrients in the pulp of 2018 season fruit showed little variation between harvests (Table 7). Fruit from Experiment 7 had lower iron, zinc and manganese levels than fruit harvested five weeks earlier for Experiment 6, but all other nutrients (and their ratios) did not differ between experiments.

Application of a postharvest fungicide in Experiment 8 did not affect body rot expression at soft-ripe stage (Table 8). As in previous experiments, more lesions and larger lesion areas were observed at the impact site in fruit dropped $30 \mathrm{~cm}$ as compared with non-impacted fruit. Disease expression outside the impact site was extensive and did not significantly differ between treatments. The overall means were $8.8 \pm 1.0\left( \pm\right.$ s.e.) and $290 \pm 40 \mathrm{~mm}^{2}$ ( \pm s.e.) for lesion number and area, respectively.

Fruit from Experiment 8 were harvested on the same day from the same orchard, albeit from a different tree, and subjected to a postharvest temperature regime that closely resembled the prompt cooling treatment of Experiment 7. The exception was a $3 \mathrm{~h}$ break in the cold chain to accommodate fungicide dipping and air drying. Despite these similarities between experiments, body rot development was seemingly more pronounced in Experiment 8 than in Experiment 7. 
Table 7. Mineral nutrients in pulp of 'Hass' avocado fruit harvested in 2018 season.

\begin{tabular}{|c|c|c|}
\hline Pulp mineral Nutrients & Experiment $6^{1}$ & Experiment $7^{1}$ \\
\hline \multicolumn{3}{|l|}{ Macronutrients (g kg-1 DW) } \\
\hline $\mathrm{N}$ & $17.3 \mathrm{a}$ & $16.4 \mathrm{a}$ \\
\hline $\mathrm{P}$ & $2.57 \mathrm{a}$ & $2.86 \mathrm{a}$ \\
\hline $\mathrm{K}$ & $26.6 \mathrm{a}$ & $24.7 \mathrm{a}$ \\
\hline $\mathrm{Mg}$ & $1.09 \mathrm{a}$ & $1.07 \mathrm{a}$ \\
\hline $\mathrm{Ca}$ & $0.44 \mathrm{a}$ & $0.41 \mathrm{a}$ \\
\hline$S$ & $1.41 \mathrm{a}$ & $1.31 \mathrm{a}$ \\
\hline \multicolumn{3}{|l|}{ Micronutrients (mg kg $\left.{ }^{-1} \mathrm{DW}\right)$} \\
\hline $\mathrm{Fe}$ & $19.7 \mathrm{a}$ & $13.4 \mathrm{~b}$ \\
\hline $\mathrm{Zn}$ & $35.0 \mathrm{a}$ & $28.2 \mathrm{~b}$ \\
\hline $\mathrm{Cu}$ & $7.6 \mathrm{a}$ & $7.5 \mathrm{a}$ \\
\hline $\mathrm{Mn}$ & $6.39 \mathrm{a}$ & $4.37 \mathrm{~b}$ \\
\hline \multicolumn{3}{|l|}{ Nutrient ratios } \\
\hline $\mathrm{N} / \mathrm{Ca}$ & $40 \mathrm{a}$ & $40 \mathrm{a}$ \\
\hline $\mathrm{K} / \mathrm{Ca}$ & $61 \mathrm{a}$ & $62 \mathrm{a}$ \\
\hline $\mathrm{Mg} / \mathrm{Ca}$ & $2.5 \mathrm{a}$ & $2.6 \mathrm{a}$ \\
\hline$(\mathrm{Ca}+\mathrm{Mg}) / \mathrm{K}$ & $0.058 \mathrm{a}$ & $0.061 \mathrm{a}$ \\
\hline$(\mathrm{K}+\mathrm{Mg}) / \mathrm{Ca}$ & $63 \mathrm{a}$ & $64 \mathrm{a}$ \\
\hline
\end{tabular}

${ }^{1}$ Means within a row that do not share a letter are significantly different $(p<0.05)$ according to Fisher's LSD test.

Table 8. Influence of impact at packing and postharvest fungicide treatment on body rot expression inside the impact site in 'Hass' avocado fruit from Experiment 8 as assessed at soft-ripe stage.

\begin{tabular}{|c|c|c|}
\hline Treatment Factor & No. Lesions ${ }^{1}$ & Lesion Area $\left(\mathrm{mm}^{2}\right)^{1}$ \\
\hline \multicolumn{3}{|l|}{ Drop height (D) } \\
\hline $0 \mathrm{~cm}$ & $0.25 \mathrm{~b}$ & $7 \mathrm{~b}$ \\
\hline $30 \mathrm{~cm}$ & $2.00 \mathrm{a}$ & $114 \mathrm{a}$ \\
\hline \multicolumn{3}{|l|}{ Fungicide (F) } \\
\hline $0 \mathrm{~mL} \mathrm{~L}^{-1}$ & $1.18 \mathrm{a}$ & $56 a$ \\
\hline $2.5 \mathrm{~mL} \mathrm{~L}^{-1}$ & $1.08 \mathrm{a}$ & $65 \mathrm{a}$ \\
\hline \multicolumn{3}{|l|}{$\mathrm{D} \times \mathrm{F}$} \\
\hline $0 \mathrm{~cm}, 0 \mathrm{~mL} \mathrm{~L}^{-1}$ & $0.30 \mathrm{~b}$ & $11 \mathrm{~b}$ \\
\hline $0 \mathrm{~cm}, 2.5 \mathrm{~mL} \mathrm{~L}^{-1}$ & $0.20 \mathrm{~b}$ & $3 \mathrm{~b}$ \\
\hline $30 \mathrm{~cm}, 0 \mathrm{~mL} \mathrm{~L}^{-1}$ & $2.05 \mathrm{a}$ & $102 \mathrm{a}$ \\
\hline $30 \mathrm{~cm}, 2.5 \mathrm{~mL} \mathrm{~L}^{-1}$ & $1.95 \mathrm{a}$ & $126 \mathrm{a}$ \\
\hline \multicolumn{3}{|l|}{$p$ value } \\
\hline Drop height (D) & $* * *$ & $* * *$ \\
\hline Fungicide $(\mathrm{F})$ & ns & ns \\
\hline $\mathrm{D} \times \mathrm{F}$ & ns & ns \\
\hline
\end{tabular}

${ }^{1}$ Means within a column and treatment factor that do not share a letter are significantly different $(p<0.05)$ according to Fisher's LSD test. ns not significant; ${ }^{* * *} p<0.001$.

In all experiments, impact-induced body rot symptoms were typical of anthracnose caused by Colletotrichum spp. Gene sequencing conducted on fungal isolates from diseased fruit in Experiment 6 confirmed this to be the case. C. siamense was found to be associated with impact-induced lesions in fruit from four of the five trees used in the experiment. C. alienum was associated with impact-induced lesions in fruit from the fifth tree. Both C. siamense and C. alienum have previously been reported as common causal agents of anthracnose (body rot) in 'Hass' avocado fruit in eastern Australia [16]. 


\section{Discussion}

All experiments in this study indicated that impact injury to unripe 'Hass' avocado fruit increased the frequency and severity of body rots subsequently observed at the eating ripe stage. Furthermore, two Colletotrichum species from the C. gloeosporioides species complex [17] were found to be associated with the impact-induced lesions, suggesting that the rots were more than likely anthracnose. The pathogenicity of C. gloeosporioides in avocado fruit has been the focus of research [18-44] and review [7,45-47]. Consequently, there is relatively good understanding of the infection processes. Quiescent infections of the fruit cuticle that occur in the orchard [18-20] are activated postharvest as the fruit ripen [21]. An increase in fruit peel $\mathrm{pH}$ above 5.8 [24] and a decline in naturally occurring antifungal compounds [22,23] during ripening have been shown to promote anthracnose development. Whether impact injury accelerates these changes in avocado is not known. However, an injury-related decline in antifungal compounds is possible. Prusky et al. [37] showed that the potent antifungal compound persin declined to sub-fungitoxic levels $6 \mathrm{~d}$ after applying multiple puncture wounds to freshly harvested 'Fuerte' avocado fruit. Persin degradation in avocado fruit has been associated with increased lipoxygenase (LOX) activity [30]. It is likely that wounding produced a rapid increase in LOX activity, as has been shown in studies on other fruit [48,49]. Although puncture and impact are different forms of mechanical injury, the latter does cause apparent mesocarp cell damage in hard green mature 'Hass' fruit [9]. Proton magnetic resonance imaging of fruit dropped $100 \mathrm{~cm}$ revealed a region of hyperintensity at the impact site, which Mazhar et al. [9] interpreted as a leakage of symplastic cellular fluids from damaged cells into apoplastic air space.

Fruit responses to impact injury in the current study did not appear to be limited to the impact site. Experiments 4, 5 and 7 showed that dropping fruit from $30 \mathrm{~cm}$ or more caused an increase in the number and/or size of lesions occurring elsewhere on the fruit. Evidence for a 'whole fruit' response to impact injury was reported by Ben-Yehoshua et al. [50]. As compared with uninjured fruit, they found an elevated respiration rate and earlier respiratory climacteric peak in 'Hass' fruit subjected to an undefined "shaking" treatment applied $1 \mathrm{~d}$ after harvest. They also reported accelerated softening of shaken fruit. However, our results (Table 6) and those of Arpaia et al. [51] showed no effect of impact injury on ripening time as measured by fruit firmness. Mechanical wounding by slicing produced an oxidative burst characterised by increased hydrogen peroxide concentration and peroxidase activity in unripe 'Hass' avocado fruit, but the response was localised to within $1 \mathrm{~cm}$ of the wound site [52]. Considering these limited and contradictory findings for avocado, it remains unclear as to what impact-related changes might account for increased disease expression across the entire fruit.

Postharvest cooling treatment had no effect on body rot development in non-impacted fruit or fruit dropped from $30 \mathrm{~cm}$. However, cooling as opposed to no cooling (Experiment 6; Figure 6) and prompt as opposed to delayed cooling (Experiment 7; Figure 8) resulted in a greater expression of body rots in fruit dropped $60 \mathrm{~cm}$. A strong impact-induced pathogen response, coupled with a longer ripening time for fruit from these cooling treatments, is a possible explanation for this interaction. Studies have shown that avocado fruit that ripen earlier are less prone to body rot development than slow-ripening fruit $[53,54]$. These findings support the view of others $[42,55]$ that fruit softening per se is not the key mediator of $C$. gloeosporioides growth. In our experiments, fruit dropped $60 \mathrm{~cm}$ and subjected to cooled or prompt cooling treatments took $\sim 1 \mathrm{~d}$ longer to ripen than their un-cooled or delayed cooling counterparts (Table 6). Disease development occurs rapidly in the latter stages of avocado ripening. An extra day at $20^{\circ} \mathrm{C}$ is capable of yielding a twofold increase in body rot incidence [54].

A rapid rate of body rot development is one likely reason for the much higher disease expression observed in Experiment 3 for soft-ripe fruit as compared with firm-ripe fruit (Table 5). Although ripening time was not recorded in this experiment, 'Hass' fruit generally require $\sim 2 \mathrm{~d}$ at $20{ }^{\circ} \mathrm{C}$ to progress from firm- to soft-ripe stage. Moreover, firm-ripe 'Hass' fruit may better resist Colletotrichum invasion if the peel contains higher levels of antifungal compounds and/or has a lower $\mathrm{pH}$ than that of soft-ripe fruit. Antifungal compound levels in 'Hass' fruit peel have been shown to decrease as fruit ripens [56]. Although ripening-related changes in peel $\mathrm{pH}$ have been established for 'Fuerte' 
fruit $[24,30]$, they are cultivar-dependent [24] and do not appear to have been investigated for 'Hass' fruit. Nonetheless, our findings suggest that impact-induced body rots pose little threat for 'Hass' fruit consumed at firm-ripe stage. However, the popularity of using avocados as a spread or in guacamole or dips [3,4] suggests that most fruit are consumed at the soft-ripe stage. For this reason, it is important that unripe fruit be carefully handled to minimise the appearance of body rots at time of consumption.

Fruit from the 2018 season (Experiments 6 to 8) showed an overall high propensity for body rot development at soft-ripe stage. Compared to values found in the literature, the pulp of these fruit contained low calcium (Ca) concentrations [57-67] and very high N concentrations [67-69], with a consequentially high N/Ca ratio of 40 . Studies on avocado fruit have revealed that both of these nutrients influence anthracnose susceptibility [58,59,67,70-76]. For example, Marques et al. [67] reported that 'Hass' fruit with a pulp N/Ca ratio of 45 developed body rots affecting $20 \%$ of the flesh volume, as opposed to just $5 \%$ in fruit that had a N/Ca ratio of 33. Ca forms cross-linkages with cell wall pectic substances, physically restricting the access of cell-wall-degrading enzymes produced by fungal pathogens [77]. Furthermore, Ca signalling in avocado mesocarp cells is believed to initiate defence responses to pathogen invasion [27]. N, however, supports anthracnose development. C. gloeosporioides uses $\mathrm{N}$ to produce ammonia, thereby raising $\mathrm{pH}$ of the surrounding environment and triggering secretion of the tissue-degrading enzyme pectate lyase (PL) [31]. Increased N supply stimulates greater PL secretion by the pathogen [28]. Nevertheless, the extent to which nutrient imbalance led to the high anthracnose susceptibility of 2018 season fruit can only be speculated. Other factors, including antifungal compound concentrations, fruit tissue $\mathrm{pH}$ and initial pathogen inoculum load, may well have contributed to the response.

Treatment of fruit with fungicide on the day after harvest had no effect on body rot development in either impacted or non-impacted fruit. Everett [78] reported that delayed postharvest application of the fungicide prochloraz reduced its efficacy. Application within $2 \mathrm{~h}$ of harvest was recommended to give the best control of rots in avocado fruit. Despite our use of a different fungicide, it may be similarly possible that the $\sim 24 \mathrm{~h}$ delay between harvest and treatment contributed to the lack of efficacy in Experiment 8. In further work, Experiment 8 might be revisited with prompter fungicide application. This would also avoid the $3 \mathrm{~h}$ cool chain break that accompanied fungicide treatment in the current study. Other researchers have shown that a $5 \mathrm{~h}$ break in the cool chain is sufficient to increase anthracnose incidence in 'Hass' avocado fruit upon ripening [79,80]. Such a phenomenon may account for the overall relatively higher body rot expression observed for fruit in Experiment 8 as compared with fruit in Experiment 7. The latter were harvested on the same day from the same orchard and subjected to the same postharvest temperature regime, but without a cool chain break.

\section{Conclusions}

This study presents compelling evidence for impact-induced body rot development in avocado fruit. Impacts of unripe 'Hass' fruit from drop heights of $30 \mathrm{~cm}$ or more promoted lesion development at the impact site and, in some cases, elsewhere on the fruit body. It is notable that these findings are in response to a single impact. In a commercial supply chain, green mature unripe fruit could conceivably be exposed to multiple impact events, which may well exacerbate the issue. It is therefore advisable to adopt careful fruit handling procedures in the early supply chain stages of fruit harvest, packing and transport to avoid unnecessary body rots occurring at retail and consumption. Supply chain stakeholders might also benefit from awareness that excessive impact injury and postharvest cooling may interact to produce a 'perfect storm', where fruits rendered more susceptible to anthracnose development are slow to ripen, and therefore at greater risk of disease. The production of fruit with a relatively low $\mathrm{N} / \mathrm{Ca}$ balance might help to mitigate the risk associated with impact-induced anthracnose. This prospect warrants further investigation, as does characterizing impact-related changes within the fruit to understand which of these promote pathogen growth. 
Author Contributions: Conceptualization, D.C.J.; methodology, D.C.J., M.L.P. and L.M.C.; formal analysis, M.L.P. and L.M.C.; investigation, D.U., B.Z. and M.L.P; resources, D.C.J. and L.M.C.; data curation, D.C.J. and M.L.P.; writing—original draft preparation, M.L.P.; writing—review and editing, D.C.J. and L.M.C.; visualization, M.L.P.; supervision, D.C.J.; project administration, M.L.P.; funding acquisition, D.C.J. All authors have read and agreed to the published version of the manuscript.

Funding: This research was funded by Hort Innovation as part of the 'Supply chain quality improvementtechnologies and practices to reduce bruising' project (AV15009), using the Hort Innovation Avocado research and development levy, co-investment from the Queensland Department of Agriculture and Fisheries, The University of Queensland, Avocados Australia Ltd. and contributions from the Australian Government. Hort Innovation is the grower-owned, not-for-profit research and development corporation for Australian horticulture.

Acknowledgments: The authors gratefully acknowledge Greg Johnson for his comments on the manuscript as well as Peter Hofman and Noel Ainsworth for their involvement in the AV15009 project in which this research was undertaken. We also thank Ken Pegg and Roger Mitchell for their support in pathogen identification and Abdullah Al Hosni, Tony Cooke, Misbah Mazhar, Sohail Mazhar and Aljay Valida for their assistance with fruit harvesting and assessment.

Conflicts of Interest: The authors declare no conflict of interest. The funders had no role in the design of the study; in the collection, analyses, or interpretation of data; in the writing of the manuscript, or in the decision to publish the results.

\section{References}

1. World Avocado Organization. Avocado Consumption in Europe and Beyond. Available online: https: //avocadofruitoflife.com/wao/wp-content/uploads/2018/08/20180727_WAO_Factsheet_Consumption.pdf (accessed on 9 November 2019).

2. Avocados Australia Limited. Facts at a Glance 2018/19 for the Australian Avocado Industry. Available online: https://www.avocado.org.au/wp-content/uploads/2019/10/2018-19_AAL-Facts-at-a-glance.pdf (accessed on 9 November 2019).

3. Hass Avocado Board. Consumer Tracking Study 2019-General Market Segment Report. Available online: https://hassavocadoboard.com/wp-content/uploads/2019/09/hab-research-insights-consumer-researchmarket-segment-report-2019.pdf (accessed on 19 November 2019).

4. Quantum Market Research. Avocado Buyer Segmentation; Final Report JN17051; Horticulture Innovation Australia: Sydney, Australia, 2017.

5. Tyas, J. Avocado Industry Fruit Quality Benchmarking; Final Report AV11015; Horticulture Innovation Australia: Sydney, Australia, 2016.

6. Gamble, J.; Harker, F.R.; Jaeger, S.R.; White, A.; Bava, C.; Beresford, M.; Stubbings, B.; Wohlers, M.; Hofman, P.J.; Marques, R.; et al. The impact of dry matter, ripeness and internal defects on consumer perceptions of avocado quality and intentions to purchase. Postharvest Biol. Technol. 2010, 57, 35-43. [CrossRef]

7. Perkins, M.L.; Joyce, D.C.; Coates, L.M. Possible contribution of impact injury at harvest to anthracnose expression in ripening avocado: A review. Sci. Hortic. 2019, 246, 785-790. [CrossRef]

8. Mazhar, M.; Joyce, D.; Hofman, P.; Vu, N. Factors contributing to increased bruise expression in avocado (Persea americana M.) cv. ‘Hass' fruit. Postharvest Biol. Technol. 2018, 143, 58-67. [CrossRef]

9. Mazhar, M.; Joyce, D.; Cowin, G.; Brereton, I.; Hofman, P.; Collins, R.; Gupta, M. Non-destructive ${ }^{1} \mathrm{H}-\mathrm{MRI}$ assessment of flesh bruising in avocado (Persea americana M.) cv. Hass. Postharvest Biol. Technol. 2015, 100, 33-40. [CrossRef]

10. Wedding, B.B.; White, R.D.; Grauf, S.; Wright, C.; Tilse, B.; Hofman, P.; Gadek, P.A. Non-destructive prediction of 'Hass' avocado dry matter via FT-NIR spectroscopy. J. Sci. Food Agric. 2011, 91, 233-238. [CrossRef] [PubMed]

11. Opara, L.U.; Al-Ghafri, A.; Agzoun, H.; Al-Issai, J.; Al-Jabri, F. Design and development of a new device for measuring susceptibility to impact damage of fresh produce. N. Z. J. Crop Hortic. Sci. 2007, 35, 245-251. [CrossRef]

12. Bill, M.; Sivakumar, D.; Thompson, A.K.; Korsten, L. Avocado fruit quality management during the postharvest supply chain. Food Rev. Int. 2014, 30, 169-202. [CrossRef]

13. White, A.; Woolf, A.; Hofman, P.J.; Arpaia, M.L. The International Avocado Quality Manual; UC Davis Press: Davis, CA, USA, 2009. 
14. Mazhar, M.; Joyce, D.; Lisle, A.; Collins, R.; Hofman, P. Comparison of firmness meters for measuring 'Hass' avocado fruit firmness. Acta Hortic. 2016, 1119, 163-169. [CrossRef]

15. Zasoski, R.J.; Burau, R.G. A rapid nitric-perchloric acid digestion method for multi-element tissue analysis. Commun. Soil Sci. Plant Anal. 1977, 8, 425-436. [CrossRef]

16. Giblin, F.; Tan, Y.; Mitchell, R.; Coates, L.; Irwin, J.; Shivas, R. Colletotrichum species associated with pre-and post-harvest diseases of avocado and mango in eastern Australia. J. Australas. Plant Pathol. Soc. 2018, 47, 269-276. [CrossRef]

17. Cannon, P.F.; Damm, U.; Johnston, P.R.; Weir, B.S. Colletotrichum-Current status and future directions. Stud. Mycol. 2012, 181-213. [CrossRef] [PubMed]

18. Coates, L.M.; Muirhead, I.F.; Irwin, J.A.; Gowanlock, D.H. Initial infection processes by Colletotrichum gloeosporioides on avocado fruit. Mycol. Res. 1993, 97, 1363-1370. [CrossRef]

19. Fitzell, R.D. Epidemiology of anthracnose disease of avocados. South Afr. Avocado Grower Assoc. Yearb. 1987, 10, 113-116.

20. Peterson, R. Susceptibility of Fuerte avocado fruit at various stages of growth, to infection by anthracnose and stem end rot fungi. Austral. J. Exp. Agric. Anim. Husb. 1978, 18, 158-160. [CrossRef]

21. Binyamini, N.; Schiffmann-Nadel, M. Latent infection in avocado fruit due to Colletotrichum gloeosporioides. Phytopathology 1972, 62, 592-594. [CrossRef]

22. Prusky, D.; Keen, N.T.; Eaks, I. Further evidence for the involvement of a preformed anti-fungal compound in the latency of Colletotrichum gloeosporioides on unripe avocado fruits. Physiol. Plant Pathol. 1983, 22, 189-198. [CrossRef]

23. Sivanathan, S.; Adikaram, N.K.B. Biological activity of four antifungal compounds in immature avocado. J. Phytopathol. 1989, 125, 97-109. [CrossRef]

24. Yakoby, N.; Kobiler, I.; Dinoor, A.; Prusky, D. pH regulation of pectate lyase secretion modulates the attack of Colletotrichum gloeosporioides on avocado fruits. Appl. Environ. Microbiol. 2000, 66, 1026-1030. [CrossRef]

25. Ardi, R.; Kobiler, I.; Jacoby, B.; Keen, N.T.; Prusky, D. Involvement of epicatechin biosynthesis in the activation of the mechanism of resistance of avocado fruits to Colletotrichum gloeosporioides. Physiol. Mol. Plant Pathol. 1998, 53, 269-285. [CrossRef]

26. Beno-Moualem, D.; Prusky, D. Early events during quiescent infection development by Colletotrichum gloeosporioides in unripe avocado fruits. Phytopathology 2000, 90, 553-559. [CrossRef]

27. Djami-Tchatchou, A.T.; Straker, C.J.; Allie, F. 454 sequencing for the identification of genes differentially expressed in avocado fruit (cv. Fuerte) infected by Colletotrichum gloeosporioides. J. Phytopathol. 2012, 160, 449-460. [CrossRef]

28. Drori, N.; Kramer-Haimovich, H.; Rollins, J.; Dinoor, A.; Okon, Y.; Pines, O.; Prusky, D. External pH and nitrogen source affect secretion of pectate lyase by Colletotrichum gloeosporioides. Appl. Environ. Microbiol. 2003, 69, 3258-3262. [CrossRef] [PubMed]

29. Guetsky, R.; Kobiler, I.; Wang, X.; Perlman, N.; Gollop, N.; Avila-Quezada, G.; Hadar, I.; Prusky, D. Metabolism of the flavonoid epicatechin by laccase of Colletotrichum gloeosporioides and its effect on pathogenicity on avocado fruits. Phytopathology 2005, 95, 1341-1348. [CrossRef] [PubMed]

30. Karni, L.; Prusky, D.; Kobiler, I.; Barshira, E.; Kobiler, D. Involvement of epicatechin in the regulation of lipoxygenase activity during activation of quiescent Colletotrichum gloeosporioides infections of ripening avocado fruits. Physiol. Mol. Plant Pathol. 1989, 35, 367-374. [CrossRef]

31. Kramer-Haimovich, H.; Servi, E.; Katan, T.; Rollins, J.; Okon, Y.; Prusky, D. Effect of ammonia production by Colletotrichum gloeosporioides on pelB activation, pectate lyase secretion, and fruit pathogenicity. Appl. Environ. Microbiol. 2006, 72, 1034-1039. [CrossRef] [PubMed]

32. Madi, L.; Wang, X.J.; Kobiler, A.; Lichter, A.; Prusky, D. Stress on avocado fruits regulates $\Delta^{9}$-stearoyl ACP desaturase expression, fatty acid composition, antifungal diene level and resistance to Colletotrichum gloeosporioides attack. Physiol. Mol. Plant Pathol. 2003, 62, 277-283. [CrossRef]

33. Marimani, M.D. Infection Process and Expression of Anti-Fungal Compounds in Avocado (Persea Americana Mill.) Fruit Infected With Colletotrichum Gloeosporioides (Penz.) Penz. \& Sacc. and Molecular Identification of Fungal Pathogens of Avocado. Master's Thesis, University of the Witwatersrand, Johannesburg, South Africa, 2011. 
34. Miyara, I.; Shafran, H.; Davidzon, M.; Sherman, A.; Prusky, D. pH Regulation of ammonia secretion by Colletotrichum gloeosporioides and its effect on appressorium formation and pathogenicity. Mol. Plant-Microbe Interact. 2010, 23, 304. [CrossRef]

35. Miyara, I.; Shafran, H.; Haimovich, H.K.; Rollins, J.; Sherman, A.; Prusky, D. Multi-factor regulation of pectate lyase secretion by Colletotrichum gloeosporioides pathogenic on avocado fruits. Mol. Plant Pathol. 2008, 9, 281-291. [CrossRef]

36. Miyara, I.; Shnaiderman, C.; Meng, X.; Vargas, W.; Diaz-Minguez, J.; Sherman, A.; Thon, M.; Prusky, D. Role of nitrogen-metabolism genes expressed during pathogenicity of the alkalinizing Colletotrichum gloeosporioides and their differential expression in acidifying pathogens. Mol. Plant-Microbe Interact. 2012, 25, 1251-1263. [CrossRef]

37. Prusky, D.; Karni, L.; Kobiler, I.; Plumbley, R.A. Induction of the antifungal diene in unripe avocado fruits: Effect of inoculation with Colletotrichum gloeosporioides. Physiol. Mol. Plant Pathol. 1990, 37, 425-435. [CrossRef]

38. Prusky, D.; Keen, N.T.; Sims, J.J.; Midland, S.L. Possible involvement of an anti-fungal diene in the latency of Colletotrichum gloeosporioides on unripe avocado fruits. Phytopathology 1982, 72, 1578-1582. [CrossRef]

39. Prusky, D.; Kobiler, I.; Fishman, Y.; Sims, J.J.; Midland, S.L.; Keen, N.T. Identification of an antifungal compound in unripe avocado fruits and its possible involvement in the quiescent infections of Colletotrichum gloeosporioides. J. Phytopathol. 1991, 132, 319-327. [CrossRef]

40. Prusky, D.; Kobiler, I.; Jacoby, B. Involvement of epicatechin in cultivar susceptibility of avocado fruits to Colletotrichum gloeosporioides after harvest. J. Phytopathol. 1988, 123, 140-146. [CrossRef]

41. Prusky, D.; McEvoy, J.L.; Leverentz, B.; Conway, W.S. Local modulation of host pH by Colletotrichum species as a mechanism to increase virulence. Mol. Plant-Microbe Interact. 2001, 14, 1105-1113. [CrossRef] [PubMed]

42. Prusky, D.; Wattad, C.; Kobiler, I. Effect of ethylene on activation of lesion development from quiescent infections of Colletotrichum gloeosporioides in avocado fruits. Mol. Plant-Microbe Interact. 1996, 9, 864-868. [CrossRef]

43. Shnaiderman, C.; Miyara, I.; Kobiler, I.; Sherman, A.; Prusky, D. Differential activation of ammonium transporters during the accumulation of ammonia by Colletotrichum gloeosporioides and its effect on appressoria formation and pathogenicity. Mol. Plant-Microbe Interact. 2013, 26, 345-355. [CrossRef]

44. Wattad, C.; Dinoor, A.; Prusky, D. Purification of pectate lyase produced by Colletotrichum gloeosporioides and its inhibition by epicatechin-A possible factor involved in the resistance of unripe avocado fruits to anthracnose. Mol. Plant-Microbe Interact. 1994, 7, 293-297. [CrossRef]

45. Dann, E.K.; Ploetz, R.C.; Coates, L.M.; Pegg, K.G. Foliar, fruit and soilborne diseases. In The Avocado: Botany, Production and Uses, 2nd ed.; Schaffer, B., Wolstenholme, B.N., Whiley, A.W., Eds.; CABI Publishing: Wallingford, UK, 2013; pp. 380-422.

46. Menge, J.A.; Ploetz, R.C. Diseases of avocado. In Diseases of Tropical Fruit Crops; Ploetz, R.C., Ed.; CABI Publishing: Wallingford, UK, 2003; pp. 35-71.

47. Prusky, D.; Lichter, A. Activation of quiescent infections by postharvest pathogens during transition from the biotrophic to the necrotrophic stage. FEMS Microbiol. Lett. 2007, 268, 1-8. [CrossRef]

48. Myung, K.; Hamilton-Kemp, T.R.; Archbold, D.D. Biosynthesis of trans-2-hexenal in response to wounding in strawberry fruit. J. Agric. Food Chem. 2006, 54, 1442-1448. [CrossRef]

49. Zhao, Y.Y.; Qian, C.L.; Chen, J.C.; Peng, Y.; Mao, L.C. Responses of phospholipase D and lipoxygenase to mechanical wounding in postharvest cucumber fruits. J. Zhejiang Univ.-Sci. B 2010, 11, 443-450. [CrossRef]

50. Ben-Yehoshua, S.; Robertson, R.N.; Biale, J.B. Respiration and internal atmosphere of avocado fruit. Plant Physiol. 1963, 38, 194-201. [CrossRef] [PubMed]

51. Arpaia, M.L.; Mitchell, F.G.; Katz, P.M.; Mayer, G. Susceptibility of avocado fruit to mechanical damage as influenced by variety, maturity and stage of ripeness. South Afr. Avocado Grower Assoc. Yearb. 1987, 10, 149-151.

52. Castro-Mercado, E.; Martinez-Diaz, Y.; Roman-Tehandon, N.; Garcia-Pineda, E. Biochemical analysis of reactive oxygen species production and antioxidative responses in unripe avocado (Persea americana Mill var Hass) fruits in response to wounding. Protoplasma 2009, 235, 67-76. [CrossRef] [PubMed]

53. Darvas, J.M.; Kotzé, J.M.; Wehner, F.C. Effect of treatment after picking on the incidence of postharvest fruit diseases of avocado. Phytophylactica 1990, 22, 93-96. 
54. Hopkirk, G.; White, A.; Beever, D.; Forbes, S. Influence of postharvest temperatures and the rate of fruit ripening on internal postharvest rots and disorders of New Zealand 'Hass' avocado fruit. N. Z. J. Crop Hortic. Sci. 1994, 22, 305-311. [CrossRef]

55. Prusky, D.; Kobiler, I.; Jacoby, B.; Sims, J.J.; Midland, S.L. Inhibitors of avocado lipoxygenase: Their possible relationship with the latency of Colletotrichum gloeosporioides. Physiol. Plant Pathol. 1985, 27, 269-279. [CrossRef]

56. Bowen, J.; Billing, D.; Connolly, P.; Smith, W.; Cooney, J.; Burdon, J. Maturity, storage and ripening effects on anti-fungal compounds in the skin of 'Hass' avocado fruit. Postharvest Biol. Technol. 2018, 146, 43-50. [CrossRef]

57. Hofman, P.; Marques, J.R.; Searle, C.; Stubbings, B.; Moody, P. Improving avocado fruit quality through tree nutrition-Present knowledge. In Proceedings of the New Zealand and Australia Avocado Grower's Conference, Tauranga, New Zealand, 20-22 September 2005; p. 15.

58. Willingham, S.L.; Coates, L.M.; Cooke, A.W.; Dean, J.R. Tree vigour influences disease susceptibility of 'Hass' avocado fruits. Australas. Plant Pathol. 2004, 33, 17-21. [CrossRef]

59. Hofman, P.J.; Vuthapanich, S.; Whiley, A.W.; Klieber, A.; Simons, D.H. Tree yield and fruit minerals concentrations influence 'Hass' avocado fruit quality. Sci. Hortic. 2002, 92, 113-123. [CrossRef]

60. Thorp, T.; Hutching, D.; Lowe, T.; Marsh, K. Survey of fruit mineral concentrations and postharvest quality of New Zealand-grown 'Hass' avocado (Persea americana Mill.). N. Z. J. Crop Hortic. Sci. 1997, 25, 251-260. [CrossRef]

61. Tingwa, P.; Young, R. The effect of calcium on the ripening of avocado (Persea americana Mill.) fruits. J. Am. Soc. Hort. Sci. 1974, 99, 540-542.

62. Barrientos-Priego, A.F.; Martinez-Damian, M.T.; Vargas-Madriz, H.; Lazaro-Dzul, M.O. Effect of preharvest calcium spraying on ripening and chilling injury in 'Hass' (Persea americana Mill.) avocado. Rev. Chapingo Ser. Hortic. 2016, 22, 145-159. [CrossRef]

63. Pedreschi, R.; Muñoz, P.; Robledo, P.; Becerra, C.; Defilippi, B.G.; van Eekelen, H.; Mumm, R.; Westra, E.; de Vos, R.C.H. Metabolomics analysis of postharvest ripening heterogeneity of 'Hass' avocadoes. Postharvest Biol. Technol. 2014, 92, 172-179. [CrossRef]

64. Witney, G.W.; Hofman, P.J.; Wolstenholme, B.N. Effect of cultivar, tree vigour and fruit position on calcium accumulation in avocado fruits. Sci. Hortic. 1990, 44, 269-278. [CrossRef]

65. Witney, G.W.; Hofman, P.J.; Wolstenholme, B.N. mineral distribution in avocado trees with reference to calcium cycling and fruit quality. Sci. Hortic. 1990, 44, 279-291. [CrossRef]

66. Reddy, M.; Moodley, R.; Jonnalagadda, S.B. Elemental uptake and distribution of nutrients in avocado mesocarp and the impact of soil quality. Environ. Monit. Assess. 2014, 186, 4519-4529. [CrossRef]

67. Marques, J.R.; Hofman, P.J.; Wearing, A.H. Rootstocks influence 'Hass' avocado fruit quality and fruit minerals. J. Horticult. Sci. Biotechnol. 2003, 78, 673-679. [CrossRef]

68. Willingham, S.L.; Pegg, K.G.; Cooke, A.W.; Coates, L.M.; Langdon, P.W.B.; Dean, J.R. Rootstock influences postharvest anthracnose development in 'Hass' avocado. Aust. J. Agric. Res. 2001, 52, 1017-1022. [CrossRef]

69. Arpaia, M.L.; Meyer, J.L.; Witney, G.W.; Bender, G.S.; Stottlemyer, D.S.; Robinson, P.R. The Cashin Creek nitrogen fertilizer trial—What did we learn? South Afr. Avocado Grower Assoc. Yearb. 1996, 80, 85-98.

70. Coates, L.M.; Dann, E.K.; Shuey, L.S.; Smith, L.A.; Dean, J.R.; Cooke, A.W.; Pegg, K.G.; Hofman, P.J.; Marques, J.R.; Stubbings, B.A.; et al. Effects of rootstock on avocado fruit quality-Assessment of postharvest disease, major cations and biochemical traits. In Proceedings of the VII World Avocado Congress 2011, Cairns, Australia, 5-9 September 2011; pp. 206-214.

71. Leonardi, J. Avocado Canopy and Orchard Floor Management; Final Report AV00007; Horticulture Australia Ltd.: Sydney, Australia, 2005.

72. Vuthapanich, S. Preharvest Practices Affecting Postharvest Quality and mineral Composition of 'Hass' Avocado Fruit. Ph.D. Thesis, The University of Queensland, St. Lucia, Australia, 2001.

73. Whiley, A.W. Rootstock Improvement for the Australian Avocado Industry_Phase 3; Final Report AV08000; Horticulture Australia Ltd.: Sydney, Australia, 2013.

74. Willingham, S.L.; Pegg, K.G.; Anderson, J.M.; Cooke, A.W.; Dean, J.R.; Giblin, F.R.; Coates, L.M. Effects of rootstock and nitrogen fertiliser on postharvest anthracnose development in Hass avocado. Australas. Plant Pathol. 2006, 35, 619-629. [CrossRef] 
75. Dann, E.K.; Coates, L.M.; Pegg, K.G.; Dean, J.R.; Cooke, A.W.; Smith, L.A.; Shuey, L.; Whiley, A.W.; Hofman, P.J.; Marques, R.; et al. Rootstock selection, nitrogen and calcium influence postharvest disease in avocado. Acta Hortic. 2016, 1120, 391-397. [CrossRef]

76. Everett, K.R.; Boyd, L.M.; Pak, H.A.; Cutting, J.G.M. Calcium, fungicide sprays and canopy density influence postharvest rots of avocado. Australas. Plant Pathol. 2007, 36, 22-31. [CrossRef]

77. Wehr, J.B.; Menzies, N.W.; Blamey, F.P.C. Inhibition of cell-wall autolysis and pectin degradation by cations. Plant Physiol. Biochem. 2004, 42, 485-492. [CrossRef]

78. Everett, K.R. Avocado fruit rots: A review of industry funded research. N. Z. Avocado Grower Assoc. Annu. Res. Rep. 2002, 2, 1-15.

79. Kruger, F.J.; Lemmer, D. Respiration and softening rates of 'Maluma' and 'Ryan' avocados and the effect that cold chain breaks have on the ripening and quality of these cultivars. South Afr. Avocado Grower Assoc. Yearb. 2012, 35, 12-20.

80. Lemmer, D.; Kruger, F.J. Effect of cold chain breaks on the ripening and quality of 'Hass' avocados. South Afr. Avocado Grower Assoc. Yearb. 2010, 33, 14-24.

(C) 2020 by the authors. Licensee MDPI, Basel, Switzerland. This article is an open access article distributed under the terms and conditions of the Creative Commons Attribution (CC BY) license (http://creativecommons.org/licenses/by/4.0/). 